\title{
Effectual entrepreneuring: sensemaking in a family-based start-up
}

\author{
Oswald Jones ${ }^{\mathrm{a}}$ and Hongqin $\mathrm{Li}^{\mathrm{b}}$
}

aCentre for Enterprise and Entrepreneurial Learning, University of Liverpool Management School, Liverpool, UK; bUniversity of Exeter Business School, Exeter, UK

\begin{abstract}
In this paper we examine the microprocesses associated with a successful business established by two young brothers (16 and 18). The study is informed by recent processual approaches to entrepreneurship associated with effectuation theory and sensemaking. We also draw on literature related to personal dispositions, which are the basis of habitual behaviours. The empirical data are drawn from a longitudinal study of an unconventional family business which was created by the two brothers while still at school. Opportunities were created, rather than discovered, by optimizing limited familial resources during the early stages of start-up. We expand effectuation theory by demonstrating the role of sensemaking (enactment, selection and retention), familial influences on dispositions (habits, heuristics and routines) and experiential learning during the first three years of operation.
\end{abstract}

CONTACT Oswald Jones O.Jones@liverpool.ac.uk

\section{Introduction}

New firms founded by family teams are regarded as being distinctive from non-family start-ups (Chang et al. 2008; Reuf 2010). Such businesses are based on various familial relationships including parental, sibling and married couples (Hedberg and Danes 2012; Lansberg 1999; Ward 1997). There is, however, surprisingly little research related to the early stages of family firms (Alsos, Carter, and Ljunggren 2014) or the role of family entrepreneurial teams (Cruz, Howorth, and Hamilton 2013). According to Morris et al. (2010), rather than following a blueprint (Shane and Delmar 2004) the creation of family firms is largely unplanned and unpredictable. In fact, as pointed out by Anderson, Jack, and Drakopoulou Dodd (2005) family business and entrepreneurship are generally regarded as distinct areas of academic attention. Recently, there has been increasing interest in combining the study of entrepreneurship and family business. There is, for example, evidence that family businesses out-survive non-family firms: 'they are more cautious, build-up slack resources, invest in longer-term relationships with stakeholders, and build more cohesive corporate cultures'

(Miller, Steier, and Le Breton-Miller 2016, 447). Therefore, the study of entrepreneurship in new ventures started by families (Steier 2007) as well as entrepreneurship in established 
family firms (Jones et al. 2013) is important for understanding those factors contributing to the development of successful entrepreneurs.

Sensemaking focuses on ways in which organizational actors, confronted with ambiguity or uncertainty, 'seek to clarify what is going on by extracting and interpreting cues from the environment' (Maitlis and Christianson 2014, 58). According to Selden and Fletcher (2015, 609) a 'sense-making subsystem' underpins the entrepreneurial process as a business idea becomes embedded in the routines and capabilities of a functioning organization. Furthermore, it is claimed that there has been 'insufficient detailed attention' given to sensemaking in family businesses (Fletcher, De Massis, and Nordqvist 2016, 10). Sensemaking can be combined with process theory to examine the interaction between entrepreneur and opportunity as a journey (Hjorth, Holt, and Steyaert 2015; McMullen and Dimov 2013; Moroz and Hindle 2012). As stated by Rondi $(2016,129)$ 'process thinking allows researchers to obtain a greater understanding about the microprocesses of change'. Based on effectuation theory ${ }^{1}$ all nascent entrepreneurs begin with three categories of 'means': their own traits, tastes and abilities, their individual knowledge sets, and their social networks (Sarasvathy 2001, 2008; Sarasvathy et al. 2014). Hence, 'effectuation' is 'a tool for problem solving when the future is unpredictable, our goals unspecified or simply unknown, and when the environment is not independent of our decisions' (Sarasvathy 2004, 525). Effectuation is based on Simon's (1959) decision theory, which indicates that rather than predicting trends in an uncertain environment it is more effective to acquire information through experiential learning (Fuerst and Zettinig 2015; Perry, Chandler, and Markova 2012; Read et al. 2017; Sarasvathy 2012). In addition, the view that opportunities have an objective reality is rejected by effectuation theorists who argue that opportunities are'endogenously constructed' through human agency (Ramoglou and Tsang 2016, 414). Hulsink and Koek $(2014,204)$ also point out that young entrepreneurs can overcome their lack of financial, social and human capital by using 'effectuation mechanisms' to mobilize support from family members and their business associates. An effectual approach to family-based entrepreneurship fulfills a number of 'non-economic objectives' such as the provision of learning opportunities, enhanced status and improved family unity (Miller, Steier, and Le Breton-Miller 2016).

As pointed out by Bryman (2012) good research is informed by the identification or formation of significant research problems. A key research problem associated with entrepreneurship is that there are few in-depth studies concerned with the everyday practices of starting new businesses (Mueller, Volery, and von Siemens 2012). In this paper, we set out to provide a better understanding of how sensemaking contributes to the creation of organizational routines in a family-based start-up. The paper is structured in the following manner: we begin with a review of literature related to family business and then examine sensemaking in the context of start-up businesses. An outline of our research methods is followed by presentation of the Jazooli data. We then demonstrate how the family-influenced dispositions of two young entrepreneurs, Sam and Ben Wilson, shaped their sensemaking activities as the business developed from a schoolboy hobby to a growing firm with a turnover of over $£ 4.5$ million in seven years. Our focus is the two brothers who formed an effective team and whose entrepreneurial abilities were'incubated' by their supportive parents (Randerson et al. 2015). The Jazooli case is important because as the authors go on to state: 'there is a paucity of research in family business' based on Sarasvathy's (2001) effectuation theory (Randerson et al. 2015, 151). 


\section{The entrepreneuring family}

It is argued by Schjoedt et al. (2013) that there are still 'considerable knowledge gaps' related to family teams involved in the creation of new businesses. In fact, they suggest that family-based teams may possess 'critical advantages in terms of access to resources, resilience to obstacles of both an economic and psychological nature' (Schjoedt et al. 2013, 2). Brannon, Wiklund, and Haynie (2013) agree that the impact of family relationships in new venture teams have been overlooked in the literature (see Cruz, Howorth, and Hamilton 2013). Based on a study of 295 team-based start-ups, Brannon, Wiklund, and Haynie (2013) established that couples were more successful than biological teams in achieving first sales because they create 'meta-identities' by combining family and entrepreneurial roles. In contrast, biological teams often encountered role conflict because of the'salience and rigidity' associated with their family roles. According to Chua, Chrisman, and Chang (2004) the performance of family businesses vary according to where in the life-cycle family involvement occurs. So-called 'born family firms tend to have entrenched values, cultures and structure arising from family involvement' (Chua, Chrisman, and Chang 2004, 38). In contrast, 'made' family firms are founded by an owner-manager and other family members join as the firm evolves.

Based on the principles of social embeddedness, Aldrich and Cliff (2003) develop a conceptual model of the family system incorporating transitions (births, marriages, deaths), resources (financial, human, informational) and the inculcation of norms and values, which influence the process of new venture creation. Consequently, opportunity recognition, resource mobilization and the development of longer-term strategies, processes and structures are strongly influenced by the family system (see Jayawarna, Jones, and Macpherson 2014). Uhlaner et al. $(2012,6)$ define the 'entrepreneuring family' as one 'that is focused on growing family wealth and protecting shared wealth by way of business value creation' (see Habbershon, Williams, and MacMillan 2003). Entrepreuring families are generally embedded in 'overlapping social systems' including a broader group of family members. A similar point is made by Johannisson $(2011,142)$ who describes entrepreneurship as a 'practice' surrounded by an organizing context, which is 'an interactively enacted shared reality that, historically and culturally embedded, manifests and reforms itself by way of personal and face-to-face exchange'. In line with the resource-based view (RBV) Rau (2014) suggests that the family itself is a source of 'valuable, rare, inimitable and non-substitutable (VRIN) resources' that are the basis of competitive advantage. Such a view draws on the concept of 'familiness' (Habbershon and Williams 1999), which incorporates intangible assets such as trust and unity to explain why family firms can outperform non-family organizations (Chang et al. 2008; Reuf 2010). Although Howorth et al. (2010) do point out that 'intertwining' business and family can create liabilities by owners seeking to protect assets at the expense of sustained entrepreneurship.

There is also literature examining the role of conflict (McKee et al. 2014) and emotions (Brundin and Härtel 2014) in family firms. As pointed out by Kellermanns and Eddleston (2004), conflict can stem from sibling rivalry, marital discord and transgenerational tensions. Family members may also be 'locked-in' to the business, which can exacerbate the potential for conflict. The dysfunctional nature of relationship conflict is created by negative emotions such as anger, distrust, animosity and rivalry between family member (McKee et al. 2014). Although relationship conflict is generally regarded as negatively related to firm performance 'cognitive and process conflict' can improve decision-making by increasing the number of 
alternatives for the business (Kellermanns and Eddleston 2004). Similarly, emotions can have a positive impact on performance by encouraging a 'collective psychological ownership' as family members regard the business as a collective enterprise (Pierce and Jussila 2009).

It is noted by Nicholson (2014) that family firms are vulnerable to conflict arising from a number of relationships including parent-offspring tensions and sibling competition. Such relationship tensions may not disrupt the family firm because of 'the desire to help and support those who share your genes, whether they be siblings, parents or offspring' (Nicholson 2014, 129). Others suggest early emotional experiences can have an 'imprinting effect' that sets a course for the future of family firms (Stanley 2010). When uncertainty is highest, decisions are based on intuition and emotion rather than the objective analysis of historical data as in established organizations (Miller and Friesen 1984). The specific characteristics of family firms have substantial implications for the governance structures, stakeholders, planning horizons, capital structures and managerial motivations (Morris et al. 2010). In summary, the nature of the family unit and their interpersonal relationships will influence entrepreneurial activities during the creation of a family-based business (Howorth et al. 2010).

\section{Sensemaking and effectual entrepreneuring}

It is essential to consider the role of sensemaking (Weick 1995) in defining entrepreneurial responses to the risks and uncertainties associated with new businesses (Hill and Levenhagen 1995). Weick (1969) argues that sensemaking is a skill based on negotiating the meaning of practical experiences by comparing available cues against available cognitive resources (Maitlis and Lawrence 2003, 2007). Drawing on complexity science (Lichtenstein 2011; McKelvey 2004), Selden and Fletcher (2015) conceptualize the 'entrepreneurial journey' as a series of transition points linking entrepreneurial sensemaking to specific artefacts including business ideas and business models. Prior experiences and education help entrepreneurs make sense of, and enact, responses to dynamic environments (Aldrich and Yang 2014; Backes-Gellner and Moog 2013; Kim, Aldrich, and Keister 2006).

When faced with situations where prior experience fails to provide solutions there are opportunities to create new outcomes and, by enacting responses, make sense in new ways (Cornelissen 2012; Holt and Cornelissen 2014). In doing so, entrepreneurs create new traces (evident in new systems, routines and material objects) and are thus deeply embedded in the environment in which they practice their craft: 'They act, and in doing so create the materials that become the constraints and opportunities they face' (Weick 1995, 31). In their extensive review of the sensemaking literature, Maitlis and Christianson (2014) summarize a number of key issues. Some researchers focus on sensemaking as cognitive processes in which individuals make use of mental maps to understand particular situations (Bingham and Kahl 2013; Fiss and Zajac 2006). An alternative view is that even individual sense-making occurs in 'a sociomaterial context' where thoughts feelings and behaviours are influenced by other actors (Maitlis and Christianson 2014,66). As Maitlis (2005) argues sensemaking is a process of social construction (Berger and Luckmann 1966) in which individuals interpret and explain sets of cues from their environments. Hence, sensemaking is a social process underpinning the actions of entrepreneurs as they begin to establish a functioning business (Selden and Fletcher 2015). 
Any entrepreneur engaging in the processes of business creation is unlikely to do so without absorbing new knowledge as a result of their learning activities (Karatas-Ozkan 2011; Wang and Chugh 2013). Previous research confirms links between sensemaking and learning when individuals and teams are operating in highly uncertain environments (Haas 2006). Sensemaking is concerned with how actors deal with the equivocality and flux associated with new organizations (Gartner, Bird, and Starr 1992). Drawing on Campbell's (1997) evolutionary epistemology, Weick, Sutcliffe, and Obstfeld (2005) conceptualize organizational change as a reciprocal process based on three stages: enactment, selection and retention $\left(\mathrm{ESR}^{2}\right)$. Enactment occurs as the actor or actors respond to environmental change by 'noticing and bracketing' available data (Weick, Sutcliffe, and Obstfeld 2005, 411). This is followed by selection as actors combine retrospective attention and mental models to create a 'plausible story'. At this stage the 'story' (mapping out a course of action, developing a business model) remains tentative and provisional. Retention of a plausible story becomes more substantive and objective as it provides guidance for further actions. Weick, Sutcliffe, and Obstfeld $(2005,414)$ continue:'The beauty of making ESR the microfoundations of organizing and sensemaking is that it makes it easier to work with other meso- and macro-level formulations'. As sensemaking means organizations 'are talked into existence' (Weick, Sutcliffe, and Obstfeld 2005, 409) Colville, Pye, and Brown $(2016,5)$ suggest the three stages of ESR can be conceptualized as 'saying' (enactment), 'seeing what I say' (selection) and 'knowledge of what I said' (retention).

'Plausibility' as a basis of sensemaking conflicts with academic theories and managerial practices, which assume that organizational effectiveness is based on the accurate interpretation of available data (Weick 1995). Rather than relying on an objective reality sensemaking occurs as entrepreneurs develop narratives to account for their actions (Garud, Schildt, and Lant 2014; Maclean, Harvey, and Chia 2012; van Werven, Bouwmeester, and Cornelissen 2015). Hence, sensemaking is concerned with 'redrafting an emerging story so that it becomes more comprehensive, and is more resilient in the face of criticism' (Weick, Sutcliffe, and Obstfeld 2005, 415). The authors argue that bracketing occurs in response to an 'amorphous' stream of experience and information. At the same time 'managers' are dealing with a range of problems and concurrently evaluating a series of different situations. While actions can be based on managerial misconceptions this may not 'curtail effective performance' (Mezias and Starbuck 2003, 15). Actions taken on the basis of a plausible story may lead to the generation of new data, creating opportunities for more dialogue, negotiation and learning (Weick, Sutcliffe, and Obstfeld 2005). This depiction of managerial decision-making is even more relevant for entrepreneurs who undertake a wide range of tasks with little time for the collection of accurate external data. This is confirmed by Cardon, Stevens, and Potter $(2011,82)$ who state:'Sensemaking may hold particular importance for entrepreneurs, who regularly face ambiguous and strategically challenging scenarios' (Cheng and Van de Ven 1996).

Aldrich and Yang (2014) suggest that there are three interrelated personal dispositions associated with entrepreneurial actions: habits, heuristics and routines. Habitual behaviour is an essential element of human activities as well as being the underpinning future 'organizational routines' (Hodgson 2009). Familial influences on habits include inherited characteristics such as conscientiousness and self-discipline (Shane et al. 2010). Parental values can also shape 'habits such as timeliness and frugality' and these attributes could contribute to 'successful start-up activities' (Aldrich and Yang 2012, 10). Based on pragmatist philosophy, 
Hodgson and Knudsen $(2004,287)$ provide an extensive discussion of links between habits and routines: 'Habits are formed through repetition of action or thought. They are influenced by prior activity and durable self-sustaining qualities. Individual habits are the basis on which nascent entrepreneurs enact emerging routines in new businesses (Aldrich and Yang 2012; Cohen, Levinthal, and Warglien 2014). As pointed out by Baron (2008) emotions and feelings are central to the habitual responses made by entrepreneurs during business start-up. Heuristics are distinctive from habits and act as simple 'rules-of-thumb' which inform decisions when individuals are short of time and resources (Aldrich and Yang 2012). This means that effective entrepreneurs do not waste time and effort trying to achieve optimal solutions. Rather, entrepreneurs accept they have to compromise and make the best of existing resources (Baker and Nelson 2005).

In the context of new business ventures, entrepreneurs' habitual behaviours and heuristics, rules of thumb for problem-solving and sensemaking, combine to establish rudimentary routines concerned with activities such as developing a simple business model based on the pricing of their products or services (Zahra, Sapienza, and Davidsson 2006). For example, Macpherson, Herbane, and Jones $(2015,282)$ state that 'activities related to resource accretion and expansion of the solution space can be considered routines that are the necessary antecedents of nascent dynamic capabilities in small firms. This necessitates a shift of attention to entrepreneuring as a social process involving discursive and social skills rather than personality traits or attributes (Zott and Huy 2007). In the approach adopted here, business creation is considered to be an inherent, co-constitutive and continuous accumulation of activities embedded in the processes of 'effectual entrepreneuring' (Clarke, Holt, and Blundel 2014; Sarasvathy 2001; Steyaert 2004). Steyaert $(2007,467)$ explains the relevance of effectuation theory: 'it gives weight to those features of a processual understanding that focus on its context of uncertainty where neither means nor ends are predetermined; instead, they are constructed in an incremental way, i.e. in the process of the making'.

In summary, 'effectual entrepreneuring' (Sarasvathy 2001; Steyaert 2007) is influenced by two factors: the entrepreneurs' dispositions reflected in their habits, heuristics and nascent routines (Aldrich and Yang 2012); secondly, the sensemaking processes of enactment, selection and retention (Weick, Sutcliffe, and Obstfeld 2005). Rather than adopting a static view of business creation, we suggest the five inter-related elements discussed above, family, sensemaking, dispositions, experiential learning and effectual entrepreneuring are in a constant state of mutability as a result of the tensions created by a dynamic environment and the firm's resource base (Tsoukas and Chia 2002).

\section{Research methods}

Reay and Zhang (2014) identified 78 qualitative family business studies in leading journals of which 15 were single case studies. However, only one paper, Steier (2007) examined business start-up and the company (ZI Probes) was not contacted until three years after it had been founded. The authors do argue that there are 'significant opportunities' for process research that addresses 'how' questions related to the dynamics of decision-making within early-stage family firms (see Rondi 2016). Based on a review of case studies in family business research, Leppäaho, Plakoyiannaki, and Dimitratos (2016) identified 75 published papers between 2000 and 2014. The majority of these case studies (67) followed what is described as 'qualitative positivism', seven studies adopted an interpretivist approach and one study 
was based on critical realism. Interpretivistic case study researchers reject the quasi-natural science assumptions associated with positivistic approaches (see Eisenhardt 1989; Yin 2009). Researchers following the interpretivist tradition regard knowledge as a socially constructed phenomenon (Berger and Luckmann 1966; Stake 2006). At the same time, it is important that researchers legitimize their methodological approach by clarifying the underlying ontological and epistemological assumptions (Leppäaho, Plakoyiannaki, and Dimitratos 2016, 169).

Adopting an interpretivistic approach means that ontologically the research is informed by reality that is relativistic and created inter-subjectively. Epistemologically, knowledge is subjectively represented as narrative, discursive and textual data (see Lindgren and Packendorff 2009). As Hamilton, Cruz, and Jack $(2017,3)$ points out, 'Narratives help our conceptual and theoretical understanding by grasping the subtleties and complexities of underlying processes behind the creation and management of a family firm'. The importance of case-based research is stressed by a number of leading researchers including Suddaby (2006). The most widely-cited authors (Eisenhardt 1989; Yin 2009) adopt a'replication logic' based on the comparison of multiple cases for theory-building. According to Dubois and Gadde (2002, 2014) abduction, or systematic combining, fits broadly within the 'interpretivist' research paradigm (Cope 2005; Riessman 2016). Systematic combining requires researchers to iterate between empirical data and theory. Consequently, abductive methods span the divide between 'theory testing' approaches (Eisenhardt 1989; Yin 2009) and grounded theory (Glaser and Strauss 1967) where theoretical ideas are 'loose and emerging' (Miles and Huberman 1994,6). Abduction means that concepts, theories and models are used to guide researchers' engagement with the empirical world and improve theoretical insight (see Dubois and Gadde 2014; Fletcher, De Massis, and Nordqvist 2016; Nordqvist 2012; Nordqvist and Melin 2010; Suddaby 2006).

This case is of interest because close family relationships shaped the dispositions of two young entrepreneurs and influenced their sensemaking activities during the crucial period of business start-up. Unlike the majority of case studies focusing on fast-growing companies, the brothers had no tangible sources of competitive advantage such as patents, copyright or brand-name. Creation of the company and its subsequent growth stemmed from Sam's ability to spot profitable opportunities, Ben's ability to build relationships with suppliers and a joint commitment to systemize their internal processes. While the Wilsons were certainly an 'entrepreneuring family' the case is significant as a 'born firm' because the business was initiated by Sam in his early teens and formally established by Ben during his 'gap'year. Even though Martin was eventually employed in the business he and Alison provided guidance, advice and support rather than taking over the company. Another significant feature of the case is that the four family members were not linked to any external support networks. Consequently, in establishing Jazooli and managing early stage growth, the family were entirely reliant on their own resources. Therefore, although access to Jazooli was serendipitous, we suggest that it fulfils Siggelkow's (2007) criteria for being an 'interesting' case study. It also concurs with Stake's (2006) view that such studies are useful and important because they demonstrate how things work for a particular case in a particular setting. The research focus is 'Verstehen (understanding) as opposed to Erklären (explanation)' in the words of Abma and Stake $(2014,1150)$.

The first author became aware of the Jazooli case as a result of working with the mother of Ben and Sam Wilson during the early 2000s. Alison often talked about Sam's entrepreneurial exploits while in primary school. When his older brother Ben formally established 
Jazooli in 2008 it presented a unique opportunity to study the creation of a family-based enterprise. Although Alison moved to another institution she remained in contact with the first author providing regular updates about the boys and their entrepreneurial venture. The 'nuclear family' is the most basic family structure (Akhter 2016) and interviews were carried out with all four family members early in 2010. Because of the interviewer's (first author) previous working relationship with Alison a considerable amount was already known about the boys and the setting-up of Jazooli. The interviewer also knew about the close relationships between parents and sons because Alison had often shared stories about their lives together when they were growing up. For example, Sam's entrepreneurial exploits in primary school, the reason Ben began working in Jazooli and the sibling rivalry this engendered, as well as their 'effectual' approach to start-up were well-known to the interviewer.

This status as family friend meant the interviews were informal and all four were happy to talk about how family life had contributed to business success. Maclean, Harvey, and Chia $(2012,22)$ confirm that such long-term relationships create a trusting environment where interviewees are more likely to disclose their deeper thoughts and feelings or what Alvesson $(2003,16)$ describes as the 'experienced social reality of the interviewee'. The interviews provided greater detail about how family relationships underpinned the success of Jazooli than would have been possible in a more formal interviewer-interviewee interaction. During the interviews, Sam and Ben were encouraged to narrate their experiences in establishing and developing the business. Martin and Alison, were asked to talk about how they had contributed to the creation and growth of Jazooli. Early in 2012 a further round of interviews took place with all four family members. They were asked to reflect on their experiences of establishing Jazooli as an operational business. Given the long-term personal relationship with Alison and, indirectly other family members, the interview schedule provided a basic structure. Follow-ups (more depth) and probes (clarifications) to were used to encourage the family to share their feelings about the entrepreneurial journey (Rubin and Rubin 1995). The data are not value-free because all observations are socially situated between 'the observer and the observed' (Denzin and Lincoln 2003, 31). Interview responses are products of interpretive practices that rely on 'interaction between participants' rather than emerging 'preformed or pure' (Holstein and Gubrium 1997, 126).

All interviews, each approximately 90 min in length, were carried out, recorded, transcribed and coded manually by the first author. Following the process of systematic combing (Dubois and Gadde 2014) coding of the interviews was based on the five core concepts outlined above: family, sensemaking (enactment, selection and retention), dispositions (habits, heuristics and routines), experiential learning and effectual entrepreneuring (Appendix). The transcribed interviewed were sent to individual family members to ensure they were accurate records of each conversation. Early drafts of the paper were also sent to all four family members to confirm they had not been misrepresented. By 2015, the company had continued its growth trajectory and the brothers had begun to consider establishing e-cigarettes as a standalone business. While Sam's early eBay trading provided the catalyst for formally establishing Jazooli we focus on the key early stages of growth from 2008 to the end of 2011 when the warehouse was fully operational and they had four full-time employees (Table 1). 
Table 1. The Jazooli timeline.

\begin{tabular}{|c|c|c|c|}
\hline & Main activities & Turnover & Full or part-time \\
\hline $2003-2007$ & $\begin{array}{l}\text { Sam begins his entrepreneurial career by selling pens/ } \\
\text { sweets in primary school and mobile phones in } \\
\text { secondary school }\end{array}$ & $\begin{array}{c}\text { Sam's pocket } \\
\text { money }\end{array}$ & None \\
\hline 2008 & $\begin{array}{l}\text { Ben leaves school and decides to take a year out before } \\
\text { university - but is unable to find sales job } \\
\text { With Sam's agreement Ben decides to gain business } \\
\text { experience by running Jazooli for } 12 \text { months. The } \\
\text { company is formally registered and begins trading } \\
\text { from Sam's bedroom. Main products - cheap iphone } \\
\text { accessories. In Ben's first year, turnover exceeds } \\
£ 70,000\end{array}$ & $£ 70 \mathrm{k}$ & $\begin{array}{l}\text { Ben full-time \& Sam } \\
\text { Part-time }\end{array}$ \\
\hline 2009 & $\begin{array}{l}\text { Based on his success during his first year Ben decides to } \\
\text { continue working in the company rather than going to } \\
\text { university to study construction. Sam continues to } \\
\text { work in the company on part-time basis } \\
\text { Ben begins to establish more formal relationships with } \\
\text { their Chinese suppliers } \\
\text { Require more storage space and move from bedroom to } \\
\text { family garage }\end{array}$ & $£ 400 \mathrm{k}$ & $\begin{array}{l}\text { Ben full-time \& Sam } \\
\text { part-time }\end{array}$ \\
\hline 2010 & $\begin{array}{l}\text { Sam leaves school and formally joins the business on } \\
\text { full-time basis } \\
\text { The boys decide that they can also invite their father, } \\
\text { Martin, to join the company (rather than working } \\
\text { away from home) } \\
\text { Martin identifies a warehouse with } 250 \text { square metre } \\
\text { capacity - move from garage }\end{array}$ & $£ 1.6 \mathrm{~m}$ & $\begin{array}{l}\text { Ben \& Sam full-time. } \\
\text { Martin also joins the } \\
\text { company }\end{array}$ \\
\hline 2011 & $\begin{array}{l}\text { Systemizing the internal business processes to enhance } \\
\text { links with suppliers and customers } \\
\text { The brothers are beginning to diversify into new } \\
\text { products: women's cosmetics and beds for pet-dogs }\end{array}$ & $£ 2.1 \mathrm{~m}$ & 4 full-time employees \\
\hline 2015 & $\begin{array}{l}\text { Diversified into e-cigarettes and consider creating a } \\
\text { separate division. Established business agreements } \\
\text { with Amazon to ship products directly from China to } \\
\text { Jazool's customers }\end{array}$ & $£ 4.5 \mathrm{~m}$ & $\begin{array}{l}10 \text { full-time } \& 5 \text { part-time } \\
\text { employees }\end{array}$ \\
\hline
\end{tabular}

\section{Case study findings: effectual family entrepreneuring}

The genesis of Jazooli occurred when Sam Wilson, while still in secondary school, began to buy and sell mobile phones on eBay to supplement his pocket-money. Sam had demonstrated a strong entrepreneurial spirit even earlier in his educational career by selling pencils and sweets to fellow junior school pupils (Table 1). Ben, Sam's older brother, took a year out before going to university to gain sales experience. Unable to secure an appropriate post he decided to acquire first-hand business experience by running Jazooli for 12 months. Following these tentative first-steps, Ben quickly established links with a number of Chinese suppliers and, as a result of very competitive pricing, sales began to grow quickly. Business activities extended from mobile phone accessories to include women's cosmetics, beds for pet-dogs and, most recently, electronic cigarettes. As demonstrated in Table 1, Sam's early trading on eBay eventually led to the formal creation of Jazooli in 2008. Subsequently, the company has grown rapidly and was turning over $£ 4.5$ million in 2015 (a growth rate of $6400 \%$ ). It was apparent that Sam's ability to spot a money-making opportunity and problems at school meant that self-employment was a likely option. At that stage, their parents were keen that Ben and Sam complete their A-level studies so they had the option of going to 
university as their older brother, James, had done. Sam was not, however, thriving in secondary school:

I was put down by a lot of my teachers and didn't enjoy school one bit, I hated it. I struggled a lot with learning, English was really bad and I didn't want to do anything. I could have done well but I didn't want to be there I wanted to start earning straight away.

Alison and Martin knew Sam was entrepreneurial from a very young age. In secondary school, he became familiar with the internet and quickly spotted the profitable potential of eBay. As Sam acknowledged, online trading had a detrimental impact on his school-work.

I was doing business studies at school and failed! I almost got kicked out of 6th form. I was doing too much probably and on my IT coursework I fell-out with the teacher. I was only there (at school) because my parents wanted me to stay-on in case I wanted to go to university. I was probably a bit 'off' with some of the teachers. When you have a business that's making money and they're telling you what to do it takes the mickey a bit.

Initially, the situation was different for Ben who anticipated spending a year working on Jazooli as a way of gaining business experience before taking-up his place at university. He was, however, also ambivalent about school even though he had obtained sponsorship for a degree in construction management.

I always wanted to earn money right from being small. I just saw school as a stepping-stone to the next stage. At that time (leaving school) it was construction management - that gave me the choice. In end I didn't want to go to university and accumulate all that debt. I knew it wasn't necessary for me and I knew that I could do it any time. (go to university) [Ben]

During the first two years he was operating the company Ben continued to live at home which minimized outgoing. There were a number of advantages related to this effectual approach, which involved very little financial investment or even the need for regular income to cover living expenses. First, the brothers were able to 'learn-by-doing' as they gradually gained business experience without being under pressure to generate large amounts of sales. This focus on experiential learning was combined with a desire by Ben and Sam to do things as professionally as possible. Secondly, the absence of direct financial pressures meant that they did not have to compromise by making hasty or inappropriate decisions. Nevertheless, as discussed below, they faced a number of crises and Martin's experience was crucial to Jazooli's survival. Thirdly, as the business began to grow they did not have to seek external finances to expand their resource base. In fact, since they began to trade seriously at the beginning of 2009 the company has always been in a strong financial position.

In the following section, we analyze the boys' dispositions (habits, heuristics and routines) and their sensemaking abilities based on the concepts of enactment, selection and retention (see Weick, Sutcliffe, and Obstfeld 2005). This method differs from the more conventional stage model approaches widely adopted in the small business literature (Levie and Lichtenstein 2010). We do suggest there were key periods of transition, which are convenient devices to punctuate the Jazooli narrative. Those transition points are their first entrepreneurial steps (enactment - noticing and bracketing), formalizing the business (selection - creating a plausible story), professionalization ${ }^{3}$ (retention - implementing organizational routines).

\section{First entrepreneurial steps: habits and enactment}

The ability to make sense of a wide-range of information is important to the success of any entrepreneurial business. Both parents acted as role-models in terms of their strong 
work-ethic and commitment to education. At the same time, they encouraged Sam, Ben and James, their older brother, to think for themselves by developing independence and self-sufficiency while they were growing-up. It is also significant that while Martin and Alison were keen to ensure that Sam and Ben completed their A-levels they did not object to them setting-up and running Jazooli. When Martin discovered how much money Sam was making on eBay he realized that it was important to formalize his activities.

It started off as a bit of hobby but it became very evident very early on that it was more than that. We didn't realise at first that he was buying and selling things on eBay long before he should have been. I think he was about 13 when we discovered he was buying second-hand mobile-phones, which he knew he could turn around to sell. The amount of pocket money he was making became significant and I said to him I think you should make this into a proper business, which in 2008 we did.

As illustrated above Sam's disaffection with school was partly a result of his frustration at not working full-time in the business. He also suffered from dyslexia, which restricted his reading ability although his parents believed that it also helped entrepreneurial skills.

Sam was dyslexic, which I knew as a mum having taught my other two boys how to read. That was the breakthrough, being on the internet he had to read. He'd hated going to the special classes, he didn't want to be different, there was a bit of a stigma attached to it. (Alison)

We didn't know until he started school that he was a bit dyslexic, not massively but on doing a bit of research we found out that dyslexics see the big picture and they aren't fussed on the detail. Richard Branson is one, Jackie Stewart is another and they have the ability to see the big picture. (Martin)

A central element of the Jazooli story is the way parental influence shaped the entrepreneurial careers of Sam and Ben. At one level, this is not surprising as the business originated in Sam's bedroom and even when the business moved to a large warehouse the brothers continued to live at home. Also, as soon as Jazooli was financially viable, Martin joined to provide his business experience on a more formal basis. Perhaps more significantly, Martin did not exert parental authority and take-over the business from Ben and Sam. He allowed them to take the lead and only stepped in when asked for advice. The responses of both brothers indicate that their upbringing was a crucial influence on the ways in which they managed the business. Equally, both boys knew their parents were available to provide emotional support as well as business and life experience. The Appendix provides quotes from all four family members demonstrating that Martin and Alison encouraged good 'habits' related to hard work, persistence and common sense. Sam could have continued this activity as a hobby but recognized the potential for making serious money from online trading. Therefore, what distinguished Jazooli from other teenage ventures was the ability to see the bigger picture related to buying and selling goods online. As Ben indicates (Appendix) they began by operating a very simple heuristic: 'buying something for less that you can sell it'.

From an early age Sam had an innate ability to 'notice and bracket' available data and that skill was the basis of his entrepreneurial career. Whether buying bundles of pencils and selling them individually to fellow pupils or finding incorrectly named mobile phones on eBay he was constantly looking for ways to make a profit. These habits underpinned the early stages of Sam's attempts to supplement his pocket-money by learning to play the eBay system. He applied two simple heuristics to his eBay trading: first he tried to find mobile phones that were wrongly identified by sellers (incorrect brand name or model number). Secondly, he delayed making a bid for the device until the last moment to ensure he could 
buy at the lowest price. The phones were immediately resold at a small profit using the correct name and model designation.

When I was 13 I started buying misspelt things on eBay and selling them with the correct spelling, dead easy! Then I started buying in bulk and selling the single ones. Memory cards was the best, 2000 memory cards when the PS3 came out and over the Christmas period I sold them all, absolutely fantastic.

He certainly spotted the potential business opportunity presented by selling cheap accessories for mobile phones and tablet computers. Since joining the company full-time in 2010 he has regularly demonstrated the ability to identify opportunities to introduce profitable new products. For example, by 2011 he considerably extended the range of products by initiating the sale of dog-beds and women's cosmetics; both ranges are now sold under Jazooli's brand name. Sam explained the basic modus operandi:

We look at our competitors on eBay and if they sell similar items to us, we'll get a product in as they've done the research. Our make-up brushes are called 'Urban Decay Naked' and the supplier charges us $\$ 3.6$ US. They're really good quality and we sell them for $£ 9.99$ and people see the quality. Another company charges $£ 96$ when they put their brand on the brushes. But for us, its about making a decent profit, don't be greedy but sell the quantity. That is where the money is, shift quantity that has always been our model, make $£ 1$ on each item and sell hundreds of them a day.

During the first nine months of operations Sam's bedroom in the family home was used for storing products. By this time, the brothers were concentrating on accessories for iphones and ipads and were selling to customers from their website rather than using eBay. Buying directly from manufactures meant their products were priced competitively and sales volume increased rapidly. As his bedroom was no longer adequate their parents, Alison and Martin, agreed to convert the family garage into storage space.

\section{Formalizing the business: heuristics and selection}

As the quote above demonstrates, a very simple heuristic underpinned the Jazooli approach to doing business: make a small profit on a high volume of products. This approach was influenced by Sam's early experience of buying and selling phones on eBay (Table 1). The boys used heuristics for a range of tasks associated with starting and running the business. Heuristics were applied to their 'business model' for making money, maintaining cash-flow, being self-funded, identifying contacts in China and concentrating on quantity rather than quality (see Appendix). Another core business heuristic was to sell directly to customers rather than using wholesalers. Low overheads meant that they could sell their products substantially cheaper than established online traders. Consequently, Sam and Ben were able to create a 'plausible story' about the way they managed their finances:

Whatever was in my bank was just spent and at that stage we weren't thinking we needed to start looking after it until a little bit later. We thought we need to start working out what money goes where and what we need to spend it on. Taking what we want, investing it and putting it back so we could buy more products and make more money. [Sam]

Until working in Jazooli during his gap-year Ben displayed little affinity for entrepreneurship and did not engage in similar money-making schemes as his younger brother. Nevertheless, after setting-up Jazooli in September 2008 he quickly developed both his business-related and his entrepreneurial skills. He realized that if the business was to succeed 
they had to source products directly from Chinese manufacturers rather than acting through intermediaries (Appendix, Selection). Ben described how he created a plausible story for the Chinese companies that were supplying products to Jazooli. Clearly in the very early stages (2008/2009) he was ordering relatively small batch sizes and he explained the narrative he provided to suppliers:

This could grow to something so let's build a relationship: the Chinese love that! Let's build a good working relationship. If the goods arrive and we're happy with them we all win and every time we doubled and tripled or whatever and just built on that. They'll deal with anybody of any size - you will pay a higher prize for a smaller quantity but they don't turn away business because who knows?

Interestingly, the Chinese companies would not advance credit and Jazooli had to pay in advance for all the goods they ordered. The first shipment from China required an advance payment of $£ 1500$.

It was a lot of money but we made $£ 6000$ back on that. The next time we put in $£ 3000$ and then $£ 6000$ and it just builds from that. I think everybody has a vision and it is good to have a vision about where you want to be and where you want to get and that evolves day to day as you don't know how things might go. (Ben)

At the end of his year spent managing Jazooli the business was doing so well that Ben decided to continue his entrepreneurial career rather than take-up a place at university. The business was growing quickly and by 2010 their father, Martin, began working full-time in the company. His long experience of self-employment proved invaluable in the early stages of the company. Sam completed his A-levels in 2010 and also joined the company on a fulltime basis. By this time turnover was rapidly increasing and they were outgrowing storage capacity in the family garage. Martin identified a 250 square metre warehouse with office space and good transport links for deliveries and mail collections.

\section{Professionalization: retention and routines}

Moving from garage to warehouse represented a significant scaling-up of the business, including taking on four employees and turnover reached $£ 1.6$ million in 2010 . In the early stages, Alison had taken on responsibility for the accounts and this was important in ensuring the business did not become over-stretched. Martin also played a crucial role by using his business experience to ensure that they boys did not get into serious difficulties with more powerful companies. Martin's history of self-employment enabled him instigate a number of activities to professionalize the business. These included helping manage suppliers, taking over the accounts from Alison and hiring new staff. Martin also provided a'steady hand' and an experienced voice to help Sam and Ben deal with a number of difficult issues as the business expanded. A well-known Japanese company filed a law-suit against Jazooli because the brothers were selling unauthorized memory cards that allowed customers to download games from the internet. Martin successfully negotiated with the Japanese company's representatives to ensure that legal proceedings were halted. Without Martin's business experience and his organizational skills other crises, such as an accident in the warehouse, could easily have resulted in the business being wound-up.

That incident led on to us having a visit from the Health and Safety Executive and then there were all the things that go with that like putting fire extinguishers in, 'no-running' signs, smoke detectors. Keeping the warehouse clean and tidy and things like the fire escapes. These are 
things I dealt with in my former career - the design and planning of offices so I knew they were important.

A major problem facing business start-ups is moving from high-levels of informality to more systematized ways of working. Entrepreneurial businesses with potential for future growth must begin to create nascent organizational routines as soon as they begin trading. This has certainly been the focus of attention in Jazooli, with Ben, in particular, keen to ensure the business worked efficiently. As illustrated in Table 1, their approach had two strands: first, establishing efficient links with suppliers and customers; secondly, ensuring that labour costs were minimized by applying software solutions.

We've actually just changed our software to one we think is going to serve us better and cost less. These things are extremely powerful, it would probably take about 6 people to manage that amount of work. So if you think on that, whereas we shell out $£ 700$ a month on this system, but if we had to pay six peoples' salary, we are so much more efficient and streamlined.

This commitment to systematize Jazooli's internal processes was central to Ben's desire to professionalize business activities. One of the most distinctive features of the case is their use of social media to engage with customers and suppliers:

When we started the business we could probably send out 200 orders a day. One person here can send out 900 orders a day because of the systems that are in place. Our most recent thing is where we use a system which sends out our messages across all of our social networks including twitter and facebook. You can have a great vision, but if the systems aren't there it won't ever work.

Sam also recognized the importance of formal systems and procedures to streamline their internal processes. In his case, he was particularly interested in identifying new products that they could stock:

I don't have a set formula for looking at competitors - it depends on the product. For example, if I go on Amazon I look through the site to see what is selling well, so go on the category and see what is selling well. I know it sounds tedious but it's useful to know what is a selling.

To summarize, the data provide extensive evidence of links between personal dispositions (habits, heuristics and routines) and the three levels of sensemaking: enactment, selection and retention. These sensemaking processes formed nascent routines within Jazooli, which enabled the brothers to integrate new systems and new employees without threatening the basic principles of their business. They recognized the importance of moving from a 'plausible story' to the creation of a more focused narrative which underpins the transition from a schoolboy venture to a professionally managed company.

\section{Effectual team learning}

The most significant element in the professionalization of Jazooli during the first three years of operation was that it was based on only the family's resources. As we have illustrated, Martin's experience of working for a UK bank followed by 20 years of self-employment was a key element in this process. It also became apparent during the interviews that an effectual approach to business start-up provided considerable opportunities for'on-the-job' learning. Both Sam and Ben recognized the importance of ensuring the business ran efficiently by adopting formalized systems to maximize cash-flow as well as managing their logistics and stock control (see above). Ben provided a number of graphic examples of learning from mistakes including this problem with UPS: 
We were going through a bad patch when we moved into the garage. About October a UPS plane that was bringing in our stock went down over Dubai and we never saw the stock. Because it appeared to be an act of God UPS wouldn't pay out any insurance and we didn't have the finances to fight that. It was unfortunate but it was a lesson learnt because we realised we could buy external insurance for all our other inbound shipments and regardless of whatever happens we know that we're covered.

Sam also engaged in experiential learning during his early online trading experiences as well as when the company became more established.

I learned because of the amount of time I spent on eBay. I was addicted and would go on every minute I had free - I was always looking for a deal and a lot of the deals I found were unbelievable. Even to this day, I can still go on and find deals. [Sam]

I'm not fussed about being called an entrepreneur. I just want a life where if I make a mistake it's on my own head. It's my own fault and at the end of the day I have to learn from it because that is what you do - the best thing you can do is learn from your mistakes. [Sam]

Clearly the fact that there were both young and computer literate helped with the professionalization process because they understood the power of applying software solutions to their organizational problems.

You take the difficult processes that take a long time for people to find and sort out in a retail store and strip them down and get rid of all that is unnecessary. Everything is a process - customers buy, orders come into the system, system prints it off, it's picked, packed, they are told it is on the way, they collect it and the customer gives you feedback that they've received it.

Sam and Ben's motivation to acquire new skills through experiential learning in order to systematize their internal processes is a key feature of this case. The ability to do so is even more remarkable given their lack of formal business education, training or experience. We have demonstrated that their family background was fundamental to making the transition from schoolboy hobby into a multi-million-pound business.

\section{Discussion: effectual entrepreneuring in family firms}

Our identification of the links between dispositions and sensemaking is important because intangible resources (knowledge, expertize, relationships and decision-making) are more 'salient' for start-up businesses than tangible resources including equipment and finance (Lichtenstein and Brush 2001). As a result of our engagement with the data, the interrelationships between five original concepts, family, sensemaking, dispositions, learning and entrepreneuring, are represented in Figure 1 (Dubois and Gadde 2014). This representation is consistent with the view that academic communities learn from the process of building and manipulating conceptual models (Morrison and Morgan 1999). It is also consistent with our interpretivistic research approach in which we are primarily concerned with understanding rather than explanation (Abma and Stake 2014). Therefore, Figure 1 is itself a sensemaking device for both authors and readers of this paper. The model helps explain links between individual dispositions and sensemaking during the process of business creating. Jazooli is an unconventional family firm because it was initiated by Sam's online trading when he was thirteen. The business was formally established by his older brother Ben (when he was 18) and Martin, their father, also joined within two years of start-up. Despite their youth, Jazooli was Sam and Ben's business with Martin adopting an advisory and mentoring role (Rau 2014). Therefore, the relationships and decision-making processes were very different than 


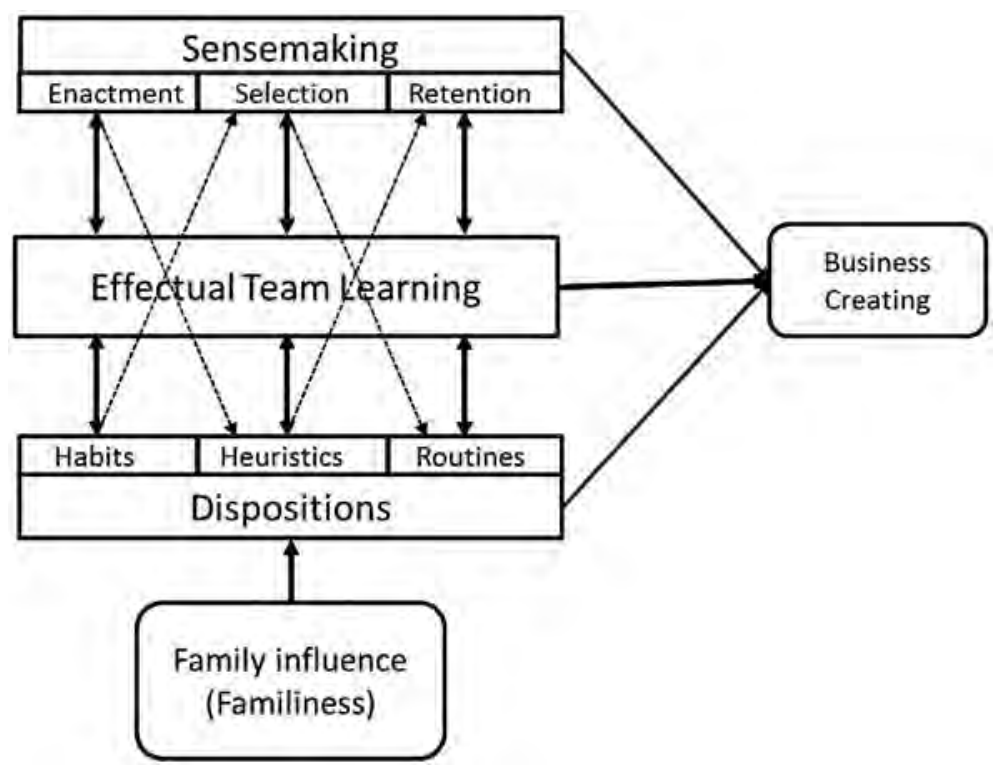

Figure 1. Effectual family business creating.

most family-based start-up teams (Brannon, Wiklund, and Haynie 2013; Chua, Chrisman, and Chang 2004). For example, in Cruz, Howorth, and Hamilton (2013) study of seven Honduran 'family entrepreneurial teams' the second generation all joined long-established businesses founded by their parents.

The family business literature stresses the importance of 'overlapping social systems' Berent-Braun and Uhlaner $(2012,106)$, which include extended family members as well as other business networks (Johannisson 2011). For the period covered by this study (20082011) the boys relied entirely on the family's own resources including significant contributions from Martin and Alison. They were not embedded in local or regional business networks which could have provided additional support, information and advice (Berent-Braun and Uhlaner 2012; Johannisson 2011; Korsgaard, Ferguson, and Gaddefors 2015). There is, as Skyrme (2011) points out, virtue in the virtuality provided by the internet, which overcomes constraints of time and distance. Founding the business was not based on conventional approaches to opportunity identification in either a Schumpetarian sense of disruptive change or a Kirtzenian view of mistakes by incumbents (Mason and Harvey 2013). The opportunities were gradually 'created' by Sam and later Ben utilizing their own limited resources in an effectual approach to business start-up (Sarasvathy 2001).

Because this was a family-based business emotions and conflict were certainly in evidence (Brundin and Härtel 2014; McKee et al. 2014). Sam was clearly irritated that Ben took the lead in developing Jazooli from his hobby into a serious business venture and this certainly contributed to his frustrations at having to remain in school. Ultimately, these tensions did not lead to any breakdown in relations between the boys when Sam joined the company on a full-time basis. Given that Ben was only two years older than Sam, there was always strong sense of sibling rivalry between the brothers. However, rather than being disruptive or dysfunctional this competitiveness had a positive impact on the business (Kellermanns and Eddleston 2004; McKee et al. 2014). They were stimulated into constantly trying to outdo 
each other in increasing sales and turnover. Sam's entrepreneurial ability to identify profitable new lines was complemented by Ben's efforts to implement a range of IT-based systems, which contributed to business efficiency and enhanced customer links. To characterize them as 'entrepreneur' (Sam) and 'manager' (Ben) would not be accurate as Sam also recognized the importance of internal systems and Ben developed the e-cigarettes opportunity which has recently become a major element of the business. Even at the very early stages of the business (2008) both recognized the importance of professionalizing their activities by ensuring the business was managed as efficiently as possible. Once Martin joined the company, his long-experience of self-employment aided the professionalization process, which, in addition to the application of IT systems, included more formal recruitment practices, financial planning procedures, formalization of decision-making and a clearer organizational structure (Dekker et al. 2015). As Howorth et al. $(2016,812)$ state,'professionalism is a process and not an event'. Jazooli was clearly at the early stages of that process as there were no plans to recruit non-family managers, develop a corporate governance structure or appoint a board of directors (Gersick and Feliu 2014).

The dispositions (Aldrich and Yang 2012; Backes-Gellner and Moog 2013) of young entrepreneurs are shaped by their parents' values and attitudes (Aldrich and Cliff 2003) during the process of effectual entrepreneuring (Sarasvathy 2001; Steyaert 2007). The concept of 'familiness' helps explain how 'valuable resources' such as experience and tacit knowledge are transferred between generations (Alsos, Carter, and Ljunggren 2014; Habbershon and Williams 1999). Biological ties mean that family team members are likely to share values which influence behaviours and decision-making (Anderson, Jack, and Drakopoulou Dodd 2005; Rau 2014). As pointed out by Sandberg and Tsoukas (2015) it is important to locate sensemaking within the institutional context where such activities actually take place. We, therefore, suggest that this study does address an important research problem by demonstrating the role of sensemaking within the context of a family-based start-up (Fletcher, De Massis, and Nordqvist 2016).

A number of authors confirm that establishing a successful start-up businesses requires entrepreneurs to engage in process of experiential learning (Wang and Chugh 2013; Wolff, Pett, and Ring 2015). Making decisions based on limited information, which may be unreliable or, at least, of uncertain provenance, is an essential feature of effectual entrepreneuring (Sarasvathy 2001). The ability to make sense of a turbulent environment must be combined with the ability to learn from the positive and negative experiences of starting new businesses. An'entrepreneurial sense-making subsystem' leads to the creation of artefacts in the form of business ideas or concepts (Selden and Fletcher 2015, 606). As demonstrated above, dispositions, habits, heuristics and routines (Aldrich and Yang 2014) influence the sensemaking processes of enactment, selection and retention (Weick, Sutcliffe, and Obstfeld 2005). We do not suggest that relationships between dispositional factors and sensemaking elements are linear (Figure 1). Rather, habits including conscientiousness, self-discipline, timeliness and frugality (Aldrich and Yang 2012; Hodgson and Knudsen 2004; Shane et al. 2010) influence enactment, selection and retention. While enactment, the'noticing and bracketing of data' (Weick, Sutcliffe, and Obstfeld 2005) will also influence the entrepreneurs' dispositions. These interactive influences will be mediated by the'effectual team learning' processes as entrepreneurs gain experience from their efforts to establish a new business. Ultimately, the influence of close family members will decline as individuals seek wider expertize and experience (Macpherson, Herbane, and Jones 2015; Überbacher 2014). 
As Hernes $(2014,39)$ explains, it is conventional to conceptualize organizations, particularly smaller ones, as adapting to environmental change between 'successive stable states'. Adopting a process perspective on the creation of entrepreneurial firms means that attempts to understand 'stabilization' is compromised by 'uncertainty and ambiguity'. Clearly, if a new firm is to become established as a functioning entity there needs to be tentative connections, with suppliers and customers which begin to develop into'stabilizing configurations' (Tsoukas and Chia 2002). The principles of sensemaking help entrepreneurial actors navigate a balance between 'unabated flux' and 'unmoderated stability' by means of narratives, which explain transitions from one set of organizational circumstances to another (Maclean, Harvey, and Chia 2012, 20). Therefore, in developing a better understanding of how entrepreneurial firms such as Jazooli become established we move beyond assumptions of stability by focusing on the dynamics and fluidity of entrepreneuring and sensemaking, which we describe as a process of entrepreneurial business creating (Tsoukas and Chia 2002).

\section{Conclusions}

Jazooli provides an excellent example of the microprocesses underpinning effectual approaches to entrepreneuring in a family-based start-up (Rondi 2016; Sarasvathy 2001; Steyaert 2004). Our unique research access was obtained as a result of work-based friendship between Alison and the first author. As demonstrated above, the brothers did not start with a clear goal to set-up their own business. Rather, the formal business idea gradually evolved as Sam's on-line trading brought his money-making activities to the attention of his parents (Selden and Fletcher 2015). We contend that their ability to manage the transition from a lucrative supplement to Sam's pocket-money into an operational business with real growth potential was strongly influenced by their parents (Bradley and Corwyn 2002; Jayawarna, Jones, and Macpherson 2014). Dispositions, based on habits, heuristics and routines, important in any entrepreneurial context, are particularly relevant in family-based start-ups (Aldrich and Yang 2012). Effective entrepreneurs know they must make the best of ambiguous information and limited resources (Cardon, Stevens, and Potter 2011). Therefore, we draw on Weick, Sutcliffe, and Obstfeld (2005) conceptualization of organizational change to illustrate how the sensemaking processes of enactment, selection and retention (ESR) formed the basis of their nascent organizational routines. The processes associated with ESR led to opportunities for dialogue, negotiation and learning (Weick, Sutcliffe, and Obstfeld 2005). We also suggest that opportunities for experiential learning (Kolb 1984) resulting from an effectual approach to business start-up are important in the Jazooli case. Sam and Ben acknowledged the significance of learning from their mistakes as the business became operational (Appendix).

In a recent evaluation of qualitative research practices, Fletcher, De Massis, and Nordqvist $(2016,23)$ point out that 'we know very little about how decisions are made or behaviours manifested in family firms'. For example, one of the most significant research problems in the entrepreneurship concerns the debate about whether opportunities are identified (Shane and Venkataraman 2000) or created (Korsgaard, Ferguson, and Gaddefors 2015; Tasavori, Zaefarian, and Ghauri 2015). Adopting a realist philosophical approach, Ramoglou and Tsang $(2016,430)$ attempt to reconcile these conflicting positions, which they suggest have been 'hindered by inadequate theorizing and 
overpowered by empiricist preconceptions'. Our research indicates that Sam and Ben did not 'create' the demand for cheap smartphone accessories amongst young people. Rather, they created the means by which they could exploit the opportunity to build a successful and profitable business (Sarasvathy et al. 2014). However, our key contribution in this paper is to deal with the problem of how sensemaking contributes to the creation of organizational routines in a family-based start-up. Rather than following the 'entrenched values, cultures and structures' (Chua, Chrisman, and Chang 2004) usually attached to family involvement, we demonstrate that the entrepreneurial actions associated with family business creating are underpinned by continuous processes of sensemaking and experiential learning. It is generally accepted that the business and management literature takes organizational stability as the norm and periods of change are regarded as exceptional and unusual events. In contrast, Tsoukas and Chia $(2002,580)$ suggest that there are always 'ongoing processes of change in organizations'. This perspective shifts the focus of attention from the static, fixed stages associated with life-cycle approaches to small firms (see Levie and Lichtenstein 2010). Instead, the Jazooli case shows that the social aspects of effectual entrepreneuring are central to the process of creating new businesses (Sarasvathy 2001).

Finally, there are policy implications which emerge from this case. It certainly demonstrates the importance of supportive mentoring for young, inexperienced entrepreneurs (see Hulsink and Koek 2014). The case also demonstrates the significance of embedding good habits such as hard-work and persistence during childhood. Support and guidance need not be parental but advice should be available from those who possess a good understanding of the challenges facing young, novice entrepreneurs. It also demonstrates the benefits of early work experience in gaining a good understanding of the way in which the world of business works (Hickie 2011). Hence, Sam's frustrations at the lack of practical relevance he experienced when studying for his A-level in information technology. Finally, Jazooli was not embedded in any regional support networks and this is a reflection of their internet-based 'business model' and the strong support provided by their parents. While we do not suggest that this approach could work for all digital businesses, it does indicate the need to consider whether or not conventional support systems for start-up businesses are still relevant.

\section{Notes}

1. See Arend, Sarooghi, and Burkemper (2015) for a critique of effectuation theory and 'response' by Read et al. (2016).

2. Breslin (2015) describes this process as variation, selection and retention.

3. In the literature on family firms, professionalization commonly refers to the shift from family control to the presence of non-family members in the management team (Dekker et al. 2015; Howorth et al. 2016). In the context of Jazooli, professionalization refers to the brothers' systematization of internal activities as a basis for the creation of nascent organizational routines (Aldrich and Yang 2014).

\section{Disclosure statement}

No potential conflict of interest was reported by the authors. 


\section{References}

Abma, T. A., and R. E. Stake. 2014. "Science of the Particular: An Advocacy on Naturalistic Case Study in Health Research." Qualitative Health Research 24 (8): 1150-1161.

Akhter, N. 2016. "Kinship and the Family Business." In Theoretical Perspectives on Family Business, edited by M. Nordqvist, L. Melin, M. Waldkirch, and G. Kumeto, 119-136. Cheltenham: Edward Elgar.

Aldrich, H. E., and J. E. Cliff. 2003. “The Pervasive Effects of Family on Entrepreneurship: Toward a Family Embeddedness Perspective." Journal of Business Venturing 18 (5): 573-596.

Aldrich, H. E., and T. Yang. 2012. "Lost in Translation: Cultural Codes Are Not Blueprints." Strategic Entrepreneurship Journal 6 (1): 1-17.

Aldrich, H. E., and T. Yang. 2014. “How Do Entrepreneurs Know What to Do? Learning and Organizing in New Ventures." Journal of Evolutionary Economics 24 (1): 59-82.

Alsos, G. A., S. Carter, and E. Ljunggren. 2014. “Kinship and Business: How Entrepreneurial Households Facilitate Business Growth." Entrepreneurship \& Regional Development 26 (1-2): 97-122.

Alvesson, M. 2003. "Beyond Neopositivists, Romantics, and Localists: A Reflexive Approach to Interviews in Organizational Research." Academy of Management Review 28 (1): 13-33.

Anderson, A., S. Jack, and S. Drakopoulou Dodd. 2005. "The Role of Family Members in Entrepreneurial Networks: Beyond the Boundaries of the Family Firm." Family Business Review 18 (2): 135-154.

Arend, R. J., H. Sarooghi, and A. Burkemper. 2015. "Effectuation as Ineffectual? Applying the 3E Theoryassessment Framework to a Proposed New Theory of Entrepreneurship." Academy of Management Review 40 (4): 630-651.

Backes-Gellner, U., and P. Moog. 2013. "The Disposition to Become an Entrepreneur and the Jacks of All Trades in Social and Human Capital." The Journal of Socio-Economics 47: 55-72.

Baker, T., and R. E. Nelson. 2005. "Creating Something from Nothing: Resource Construction through Entrepreneurial Bricolage." Administrative Science Quarterly 50 (3): 329-366.

Baron, R. A. 2008. "The Role of Effect in the Entrepreneurial Process." Academy of Management Review 33 (2): 328-340.

Berent-Braun, M. M., and L. M. Uhlaner. 2012. "Family Governance and Teambuilding: Paradox of the Enterprising Family." Small Business Economics 38: 103-119.

Berger, P. L., and T. Luckmann. 1966. The Social Construction of Reality: A Treatise in the Sociology of Knowledge. Garden City, NY: Anchor.

Bingham, C. B., and S. J. Kahl. 2013."The Process of Schema Emergence: Assimilation, Deconstruction, Unitization and the Plurality of Analogies." Academy of Management Journal 56 (1): 14-34.

Bradley, R. H., and R. F. Corwyn. 2002. "Socioeconomic Status and Child Development." Annual Review of Psychology 53 (1): 371-399.

Brannon, D. L., J. Wiklund, and J. M., Haynie. 2013. "The Varying Effects of Family Relationships in Entrepreneurial Teams." Entrepreneurship Theory and Practice 37 (1): 107-132.

Breslin, D. 2015. "Learning to Evolve: Developing a Practice-based Evolutionary Language of Entrepreneurial Learning." In Entrepreneurial Learning: New Perspectives in Research, Education and Practice, edited by D. Rae and C. Wang, 216-234. London: Routledge.

Brundin, E., and C. E. J. Härtel. 2014. "Emotions in Family Firms." In The SAGE Handbook of Family Business, edited by L. Melin, M. Nordqvist, and P. Sharma, 529-548. London: Sage.

Bryman, A. 2012. Social Research Methods. Oxford: Oxford University Press.

Campbell, D. T. 1997. “From Evolutionary Epistemology via Selection Theory to a Sociology of Scientific Validity." Evolution and Cognition 3 (1): 5-38.

Cardon, M. S., C. E. Stevens, and D. R. Potter. 2011. “Misfortunes or Mistakes? Cultural Sensemaking of Entrepreneurial Failure." Journal of Business Venturing 26 (1): 79-92.

Chang, E. P. C., J. J. Chrisman, J. H. Chua, and F. W. Kellermanns. 2008. "Regional Economy as a Determinant of the Prevalence of Family Firms in the United States: A Preliminary Report." Entrepreneurship Theory and Practice 32 (3): 559-573.

Cheng, Y.-T., and A. H. Van de Ven. 1996. "Learning the Innovation Journey: Order out of Chaos?" Organization Science 7 (6): 593-614.

Chua, J. H., J. J. Chrisman, and E. P. C. Chang. 2004. “Are Family Businesses Born or Made? An Exploratory Investigation." Family Business Review 17 (1): 37-54. 
Clarke, J., R. Holt, and R. Blundel. 2014. “Re-imagining the Growth Process: (Co)-evolving Metaphorical Representations of Entrepreneurial Growth." Entrepreneurship \& Regional Development 26 (3/4): 234-256.

Cohen, M. D., D. A. Levinthal, and M. Warglien. 2014. “Collective Performance: Modelling the Interaction of Habit-based Actions." Industrial and Corporate Change 23 (2): 329-360.

Colville, I., A. Pye, and A. Brown. 2016. "Sensemaking Processes and Weikarious Learning." Management Learning 47 (1): 3-13.

Cope, J. 2005. "Researching Entrepreneurship through Phenomenological Inquiry: Philosophical and Methodological Issues." International Small Business Journal 23 (2): 159-183.

Cornelissen, J. 2012. "Sensemaking under Pressure: The Influence of Professional Roles and Social Accountability on the Creation of Sense." Organization Science 23 (1): 118-137.

Cruz, A. D., C. Howorth, and E. Hamilton. 2013. "Intrafamily Entrepreneurship: The Formation and Membership of Family Entrepreneurial Teams." Entrepreneurship Theory and Practice 37 (1): 17-46.

Dekker, J., N. Lybaert, T. Steijvers, and B. Depaire. 2015. “The Effect of Family Business Professionalization as a Multidimensional Construct on Firm Performance." Journal of Small Business Management 53 (2): $516-538$.

Denzin, N. K., and Y. S. Lincoln. 2003.“Introduction: The Discipline and Practice of Qualitative Research.” In The Landscape of Qualitative Research. 2nd ed., edited by N. K. Denzin and Y. S. Lincoln, 1-47. London: Sage.

Dubois, A., and L.-E. Gadde. 2002. "Systematic Combining: An Abductive Approach to Case Research." Journal of Business Research 55 (7): 553-560.

Dubois, A., and L.-E. Gadde. 2014. "Systematic Combining: A Decade Later." Journal of Business Research 67 (6): 1277-1284.

Eisenhardt, K. M. 1989. “Building Theories from Case Study Research." Academy of Management Review 14 (4): 532-550.

Fiss, P. C., and E. J. Zajac. 2006. “The Symbolic Management of Strategic Change: Sensegiving via Framing and Decoupling." The Academy of Management Journal 49 (6): 1173-1193.

Fletcher, D., A. De Massis, and M. Nordqvist. 2016. “Qualitative Research Practices and Family Business Scholarship: A Review and Future Research Agenda." Journal of Family Business Strategy 7 (1): 8-25.

Fuerst, S., and P. Zettinig. 2015. "Knowledge Creation Dynamics within the International New Venture." European Business Review 27 (2): 182-213.

Garud, R., H. A. Schildt, and T. K. Lant. 2014. “Entrepreneurial Storytelling, Future Expectations, and the Paradox of Legitimacy." Organization Science 25 (5): 1479-1492.

Gartner, W. B., B. J. Bird, and J. A. Starr. 1992. "Acting as If: Differentiating Entrepreneurial from Organizational Behaviour." Entrepreneurship: Theory and Practice 16 (3): 13-31.

Gersick, K. E., and N. Feliu. 2014. "Governing the Family Enterprise: Practices, Performance and Research." In The SAGE Handbook of Family Business, edited by L. Melin, M. Nordqvist, and P. Sharma, 196-225. London: Sage.

Glaser, B. G., and A. L. Strauss. 1967. The Discovery of Grounded Theory. Chicago, IL: Aldine.

Habbershon, T., and M. Williams. 1999. "A Resource-based Framework for Assessing the Strategic Advantages of Family Firms." Family Business Review 12 (1): 1-25.

Habbershon, T., M. Williams, and I. C. MacMillan. 2003. "A Unified Systems Perspective of Family Firm Performance." Journal of Business Venturing 18: 451-465.

Haas, M. 2006. “Knowledge Gathering, Team Capabilities, and Project Performance in Challenging Work Environments." Management Science 52 (8): 1170-1184.

Hamilton, E., A. D. Cruz, and S. Jack. 2017. "Re-framing the Status of Narrative in Family Business Research: Towards an Understanding of Families in Business." Journal of Family Business Strategy 8 (1): 3-12. doi:10.1016/j.jfbs.2016.11.001.

Hedberg, P. R., and S. M. Danes. 2012. “Explorations of Dynamic Power Processes within Copreneurial Couples." Journal of Family Business Strategy 3 (4): 228-238.

Hernes, T. 2014. A Process Theory of Organization. Oxford: Oxford University Press.

Hickie, J. 2011. "The Development of Human Capital in Young Entrepreneurs." Industry and Higher Education 25 (6): 469-481. 
Hill, R. C., and M. Levenhagen. 1995. "Metaphors and Mental Models: Sensemaking and Sensegiving in Innovative and Entrepreneurial Activities." Journal of Management 21 (6): 1057-1074.

Hjorth, D., R. Holt, and C. Steyaert. 2015. "Entrepreneurship and Process Studies." International Small Business Journal 33 (6): 599-611.

Hodgson, G. M. 2009. “The Nature and Replication of Routines." In Organizational Routines: Advancing Empirical Research, edited by M. C. Becker and N. Lazaric, 26-44. Cheltenham: Edward Elgar.

Hodgson, G. M., and T. Knudsen. 2004. "The Firm as an Interactor: Firms as Vehicles for Habits and Routines." Journal of Evolutionary Economics 14: 281-307.

Holstein, J. A., and J. F. Gubrium. 1997. "Active Interviewing." In Qualitative Research: Theory, Method and Practice, edited by D. Silverman, 113-129. London: Sage.

Holt, R., and J. Cornelissen. 2014. "Sensemaking Revisited." Management Learning 45 (5): 525-539.

Howorth, C., M. Rose, E. Hamilton, and P. Westhead. 2010. “Family Firm Diversity and Development: An Introduction." International Small Business Journal 28 (5): 437-451.

Howorth, C., M. Wright, P.Westhead, and D. Allcock. 2016. “Company Metamorphosis: Professionalization Waves, Family Firms and Management Buyouts." Small Business Economics 47: 803-817.

Hulsink, W., and D. Koek. 2014. "The Young, the Fast and the Furious: A Study about the Triggers and Impediments of Youth Entrepreneurship." International Journal of Entrepreneurship and Innovation Management 18 (2/3): 182-208.

Jayawarna, D., O. Jones, and A. Macpherson. 2014. “Entrepreneurial Potential: The Role of Human and Cultural Capitals." International Small Business Journal 32 (8): 918-943.

Johannisson, B. 2011. "Towards a Practice Theory of Entrepreneuring." Small Business Economics 36 (2): 135-150.

Jones, O., A. Ghobadian, V. Antcliffe, and N. O'Regan. 2013. “Dynamic Capabilities in a Sixth-generation Family Firm: Entrepreneurship and the Bibby Line." Business History 55 (6): 910-941.

Karatas-Ozkan, M. 2011. “Understanding Relational Qualities of Entrepreneurial Learning: Towards a Multi-layered Approach." Entrepreneurship and Regional Development 23 (9-10): 877-906.

Kellermanns, F. W., and K. Eddleston. 2004. "Feuding Families:When Conflict Does a Family Firm Good." Entrepreneurship: Theory and Practice 28 (3): 209-228.

Kim, P. H., H. E. Aldrich, and L. A. Keister. 2006. "Access (Not) Denied: The Impact of Financial, Human, and Cultural Capital on Entrepreneurial Entry in the United States." Small Business Economics 27 (1): 5-22.

Kolb, D. A. 1984. Experiential Learning: Experience as the Source of Learning and Development. Englewood Cliffs, NJ: Prentice-Hall.

Korsgaard, S., R. Ferguson, and J. Gaddefors. 2015. "The Best of Both Worlds: How Rural Entrepreneurs Use Placial Embeddedness and Strategic Networks to Create Opportunities." Entrepreneurship \& Regional Development 27 (9/10): 574-598.

Lansberg, I. 1999. Succeeding Generations: Realising the Dreams of Families in Business. Boston, MA: Harvard Business School Press.

Leppäaho, T., E. Plakoyiannaki, and P. Dimitratos. 2016."The Case Study in Family Business: An Analysis of Current Research Practices and Recommendations." Family Business Review 29 (2): 159-173.

Levie, J., and B. Lichtenstein. 2010. "A Terminal Assessment of Stages Theory: Introducing a Dynamic States Model." Entrepreneurship: Theory and Practice 34 (2): 317-350.

Lichtenstein, B. B. 2011. "Complexity Science Contributions to the Field of Entrepreneurship." In The Sage Handbook of Complexity and Management, edited by P. Allen, S. Maguire, and B. McKelvey, 471-493. Thousand Oaks, CA: Sage.

Lichtenstein, B. B., and C. G. Brush. 2001. "How Do 'Resource Bundles' Develop and Change in New Ventures? A Dynamic Model and Longitudinal Exploration." Entrepreneurship: Theory and Practice 25 (3): 37-59.

Lindgren, M., and J. Packendorff. 2009. "Social Constructionism and Entrepreneurship: Basic Assumptions and Consequences for Theory and Research." International Journal of Entrepreneurial Behavior \& Research 15 (1): 25-47.

Macpherson, A., B. Herbane, and O. Jones. 2015. “Developing Dynamic Capabilities through Resource Accretion: Expanding the Entrepreneurial Solution Space." Entrepreneurship \& Regional Development 27 (5/6): 259-291. 
Maclean, M., C. Harvey, and R. Chia. 2012. “Sensemaking, Storytelling and the Legitimization of Elite Business Careers." Human Relations 65 (1): 17-40.

Maitlis, S. 2005. "The Social Processes of Organizational Sensemaking." Academy of Management Journal 48 (1): 21-49.

Maitlis, S., and M. Christianson. 2014. "Sensemaking in Organizations: Taking Stock and Moving Forward." The Academy of Management Annals 8 (1): 57-125.

Maitlis, S., and T. B. Lawrence. 2003. "Orchestral Manoeuvres in the Dark: Understanding Failure in Organizational Strategizing." Journal of Management Studies 40 (1): 109-139.

Maitlis, S., and T. B. Lawrence. 2007. "Triggers and Enablers of Sensegiving in Organizations." Academy of Management Journal 50 (1): 57-84.

Mason, C., and C. Harvey. 2013. "Entrepreneurship: Context, Opportunities and Processes." Business History 55 (1): 1-8.

McKee, D., T. Madden, F. W. Kellermanns, and K. A. Eddleston. 2014. "Conflicts in Family Firms: The Good and the Bad." In The SAGE Handbook of Family Business, edited by L. Melin, M. Nordqvist, and P. Sharma, 514-528. London: Sage.

McKelvey, B. 2004. “Toward a Complexity Science of Entrepreneurship." Journal of Business Venturing 19 (3): 313-341.

McMullen, J. S., and D. Dimov. 2013. “Time and the Entrepreneurial Journey: The Problem and Promise of Studying Entrepreneurship as a Process." Journal of Management Studies 50 (8): 481-1512.

Mezias, J. M., and W. H. Starbuck. 2003. "Managers and Their Inaccurate Perceptions: Good, Bad or Inconsequential?" British Journal of Management 14 (1): 3-17.

Miles, M. B., and M. Huberman. 1994. Qualitative Data Analysis. Thousand Oaks, CA: Sage.

Miller, D., and P. H. Friesen. 1984. "A Longitudinal Study of the Corporate Life Cycle." Management Science 30: 1161-1183.

Miller, D., L. Steier, and I. Le Breton-Miller. 2016. “What Can Scholars of Entrepreneurship Learn from Sound Family Businesses?" Entrepreneurship: Theory and Practice 40 (3): 445-455.

Moroz, P. W., and K. Hindle. 2012. "Entrepreneurship as a Process: Toward Harmonizing Multiple Perspectives." Entrepreneurship Theory and Practice 36 (4): 781-818.

Morris, M. H., J. A. Allen, D. F. Kuratko, and D. Brannon. 2010. "Experiencing Family Business Creation: Differences between Founders, Nonfamily Managers, and Founders of Non-family Firms." Entrepreneurship Theory and Practice 34 (6): 1057-1084.

Morrison, M., and M. S. Morgan. 1999. "Models as Mediating Instruments." In Models as Mediators: Perspectives on Natural and Social Sciences, edited by M. S. Morgan and M. Morrison, 10-37. Cambridge: Cambridge University Press.

Mueller, S., T. Volery, and B. von Siemens. 2012.“What Do Entrepreneurs Actually Do? An Observational Study of Entrepreneurs' Everyday Behavior in the Start-up and Growth Stages." Entrepreneurship: Theory and Practice 36 (5): 995-1017.

Nicholson, N. 2014. "Evolutionary Theory: A New Synthesis for Family Business Thought and Research." In The SAGE Handbook of Family Business, edited by L. Melin, M. Nordqvist, and P. Sharma, 119-136. London: Sage.

Nordqvist, M. 2012. “Understanding Strategy Processes in Family Firms: Exploring the Roles of Actors and Areanas." International Small Business Journal 30 (1): 24-40.

Nordqvist, M., and L. Melin. 2010. "The Promise of the Strategy-as-practice Perspective for Family Business Strategy Research." Journal of Family Business Strategy 1 (1): 15-25.

Perry, J.T., G. N. Chandler, and G. Markova. 2012. “Entrepreneurial Effectuation: A Review and Suggestions for Future Research." Entrepreneurship: Theory \& Practice 36 (4): 837-861.

Pierce, J. L., and I. Jussila. 2009. “Collective Psychological Ownership within the Work and Organizational Context: Construct Introduction and Elaboration." Journal of Organizational Behavior 31: 810-834.

Ramoglou, S., and E. Tsang. 2016. "A Realist Perspective of Entrepreneurship: Opportunities as Propensities." Academy of Management Review 41 (3): 410-434.

Randerson, K., C. Bettinelli, A. Fayolle, and A. Anderson. 2015. "Family Entrepreneurship as a Field of Research: Exploring Its Contours and Contents." Journal of Family Business Strategy 6 (3): 143-154.

Rau, S. 2014. "Resource-based View of Family Firms." In The SAGE Handbook of Family Business, edited by L. Melin, M. Nordqvist, and P. Sharma, 321-339. London: Sage. 
Read, S., S. Sarasvathy, N. Dew, and R. Wiltbank. 2016. “Response to Arend, Sarooghi, and Burkemper (2015): Cocreating Effectual Entrepreneurship Research." Academy of Management Review 41 (3): 528-536.

Read, S., S. Sarasvathy, N. Dew, R. Wiltbank, and A.-V. Ohisson. 2017. Effectual Entrepreneurship. 2nd ed. London/New York: Routledge/Taylor and Francis.

Reay, T., and Z. Zhang. 2014. "Qualitative Methods in Family Business Research." In The SAGE Handbook of Family Business, edited by L. Melin, M. Nordqvist and P. Sharma, 573-593. London: Sage.

Reuf, M. 2010. The Entrepreneurial Group: Social Identities, Relations, and Collective Action. Princeton, NJ: Princeton University Press.

Riessman, C. K. 2016. "What's Different about Narrative Inquiry? Cases, Categories and Contexts." In Qualitative Research. 4th ed., edited by D. Silverman, 363-378. London: Sage.

Rondi, E. 2016. "Process Thinking and the Family Firm." In Theoretical Perspectives on Family Business, edited by M. Nordqvist, L. Melin, M. Waldkirch, and G. Kumeto, 119-136. Cheltenham: Edward Elgar.

Rubin, H., and I. Rubin. 1995. Qualitative Interviews: The Art of Hearing Data. London: Sage.

Sandberg, J., and H. Tsoukas. 2015. "Making Sense of the Sensemaking Perspective: Its Constituents, Limitations and Opportunities for Future Development." Journal of Organizational Behavior 36 (SI): 6-32.

Sarasvathy, S. D. 2001. "Causation and Effectuation: Toward a Theoretical Shift from Economic Inevitability to Entrepreneurial Contingency." Academy of Management Review 25 (2): 243-263.

Sarasvathy, S. D. 2004. "Making It Happen: Beyond Theories of the Firm to Theories of Firm Design." Entrepreneurship: Theory and Practice 28 (6): 519-531.

Sarasvathy, S. D. 2008. Effectuation: Elements of Entrepreneurial Expertise. Cheltenham: Edward Elgar.

Sarasvathy, S. D. 2012. "Effectuation and Entrepreneurship." In Enterprise and Small Business: Principles, Practice and Policy. 3rd ed., edited by S. Carter and D. Jones-Evans, 135-151. Harlow: Pearson.

Sarasvathy, S., K. Kumar, J. G. York, and S. Bhagavatula. 2014. "An Effectual Approach to International Entrepreneurship: Overlaps, Challenges, and Provocative Possibilities." Entrepreneurship: Theory and Practice 38 (1): 79-93.

Schjoedt, L., E. Monsen, A. Pearson, T. Barnett, and J. J. Chrisman. 2013. “New Venture and Family Business Teams: Understanding Team Formation, Composition, Behaviors, and Performance." Entrepreneurship: Theory and Practice 37 (1): 1-15.

Selden, P. D., and D. E. Fletcher. 2015. "The Entrepreneurial Journey as an Emergent Hierarchical System of Artefact-creating Processes." Journal of Business Venturing 30 (4): 605-615.

Shane, S., and F. Delmar. 2004. "Planning for the Market: Business Planning before Marketing and Continuation of Marketing Efforts." Journal of Business Venturing 19 (6): 767-785.

Shane, S., N. Nicolaou, L. Cherkas, and T. D. Spector. 2010. "Genetics, the Big Five, and the Tendency to Be Self-employed." Journal of Applied Psychology 95 (6): 1154-1162.

Shane, S., and S. Venkataraman. 2000. “The Promise of Entrepreneurship as a Field of Research." Academy of Management Review 25 (1): 217-226.

Siggelkow, N. J. 2007. “Persuasion with Case Studies." Academy of Management Journal 50 (1): 20-24.

Simon, H. A. 1959. "Theories of Decision Making in Economics and Behavioural Science." American Economic Review 49 (3): 253-283.

Skyrme, D. 2011. Knowledge Networks: Creating the Collaborative Enterprise. Abingdon: Routledge.

Stake, R. E. 2006. Multiple Case Study Analysis. New York: Guildford.

Stanley, L. 2010. "Emotions and Family Business Creation: An Extension and Implications." Entrepreneurship: Theory and Practice 34(6): 1085-1092.

Steier, L. 2007. "New Venture Creation and Organization: A Familial Sub-narrative." Journal of Business Research 60 (10): 1099-1107.

Steyaert, C. 2004. "The Prosaics of Entrepreneurship." In Narrative and Discursive Approaches in Entrepreneurship, edited by D. Hjorth and C. Steyaert, 8-21. Cheltenham: Edward Elgar.

Steyaert, C. 2007. “Entrepreneuring as a Conceptual Attractor? A Review of Process Theories in 20 Years of Entrepreneurship Studies." Entrepreneurship \& Regional Development 19 (6): 453-477.

Suddaby, R. 2006. "What Grounded Theory is Not." Academy of Management Journal 49 (4): 633-642.

Tasavori, M., R. Zaefarian, and P. N. Ghauri. 2015. “The Creation View of Opportunities at the Base of the Pyramid." Entrepreneurship \& Regional Development 27 (1-2): 106-126. 
Tsoukas, H., and R. Chia. 2002. "On Organizational Becoming: Rethinking Organizational Change." Organization Science 13 (5): 567-582.

Überbacher, F. 2014. "Legitimation of New Ventures: A Review and Research Programme." Journal of Management Studies 51 (4): 667-698.

Uhlaner, L. M., F. W. Kellermanns, K. A. Eddleston, and F. Hoy. 2012. “The Entrepreneuring Family: A New Paradigm for Family Business Research." Small Business Economics 38: 1-11.

Ward, J. L. 1997. "Growing the Family Business: Special Challenges and Best Practices." Family Business Review 10 (4): 323-337.

Wang, C. L., and Chugh, H. 2013. "Entrepreneurial Learning: Past Research and Future Challenges." International Journal of Management Reviews 16 (1): 24-61.

Weick, K. E. 1969. The Social Psychology of Organizing. Reading, MA: Addison-Wesley.

Weick, K. E. 1995. Sensemaking in Organizations. Thousand Oaks, CA: Sage.

Weick, K. E., K. M. Sutcliffe, and D. Obstfeld. 2005. "Organizing and the Process of Sensemaking." Organization Science 16 (4): 409-421.

van Werven, R., O. Bouwmeester, and J. Cornelissen. 2015. "The Power of Arguments: How Entrepreneurs Convince Stakeholders of the Legitimate Distinctiveness of Their Ventures." Journal of Business Venturing 30 (4): 616-631.

Wolff, J. A., T. L. Pett, and J. K. Ring. 2015. "Small Firm Growth as a Function of Both Learning Orientation and Entrepreneurial Orientation." International Journal of Entrepreneurial Behaviour \& Research 21 (5): 709-730.

Yin, R. 2009. Case Study Research Design and Methods. 4th ed. Thousand Oaks, CA: Sage.

Zahra, S. A., H. Sapienza, and P. Davidsson. 2006. “Entrepreneurship and Dynamic Capabilities: A Review, Model and Research Agenda." Journal of Management Studies 43 (4): 917-955.

Zott, C., and Q. N. Huy. 2007. "How Entrepreneurs Use Symbolic Management to Acquire Resources." Administrative Science Quarterly 52 (1): 70-105. 


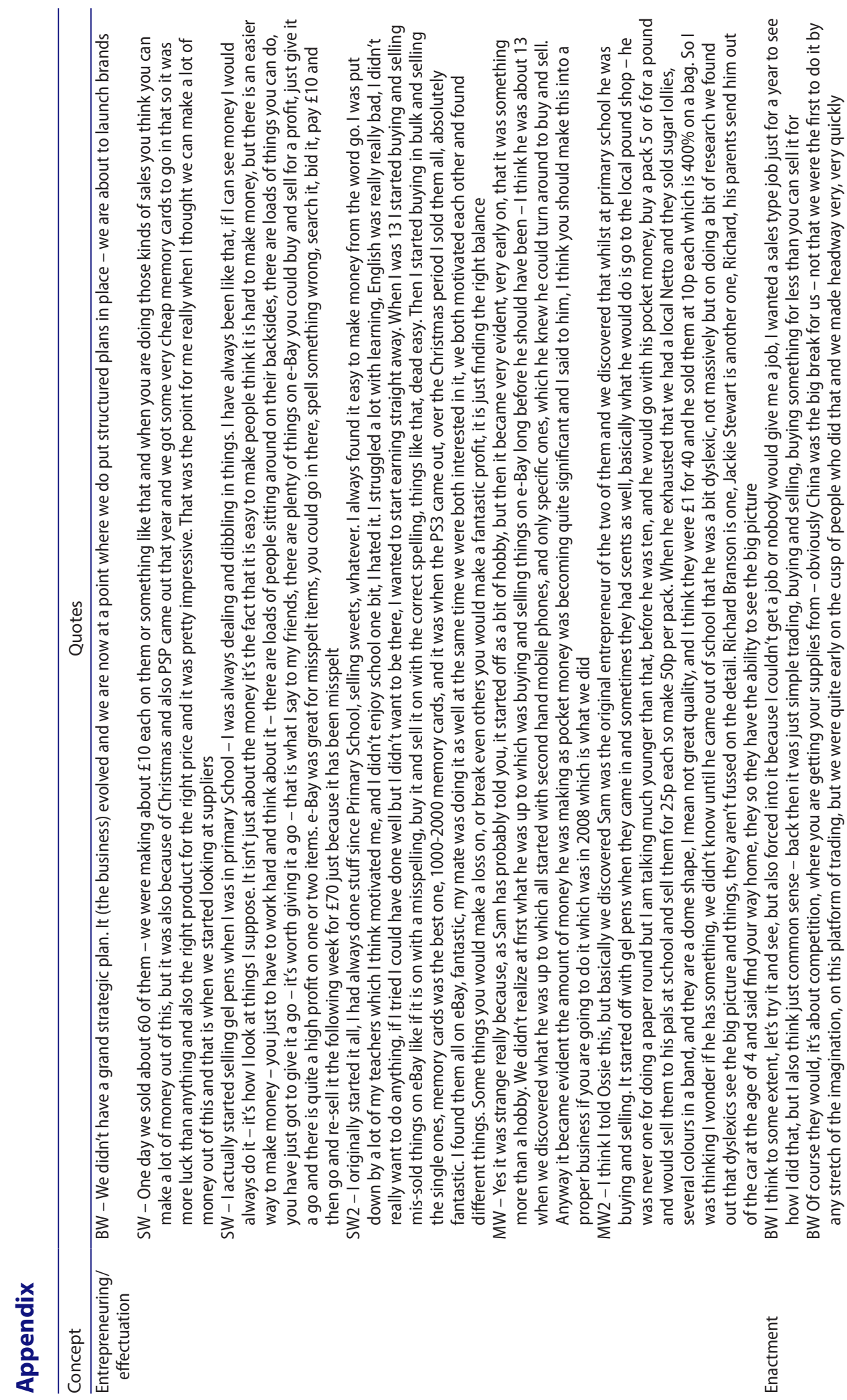




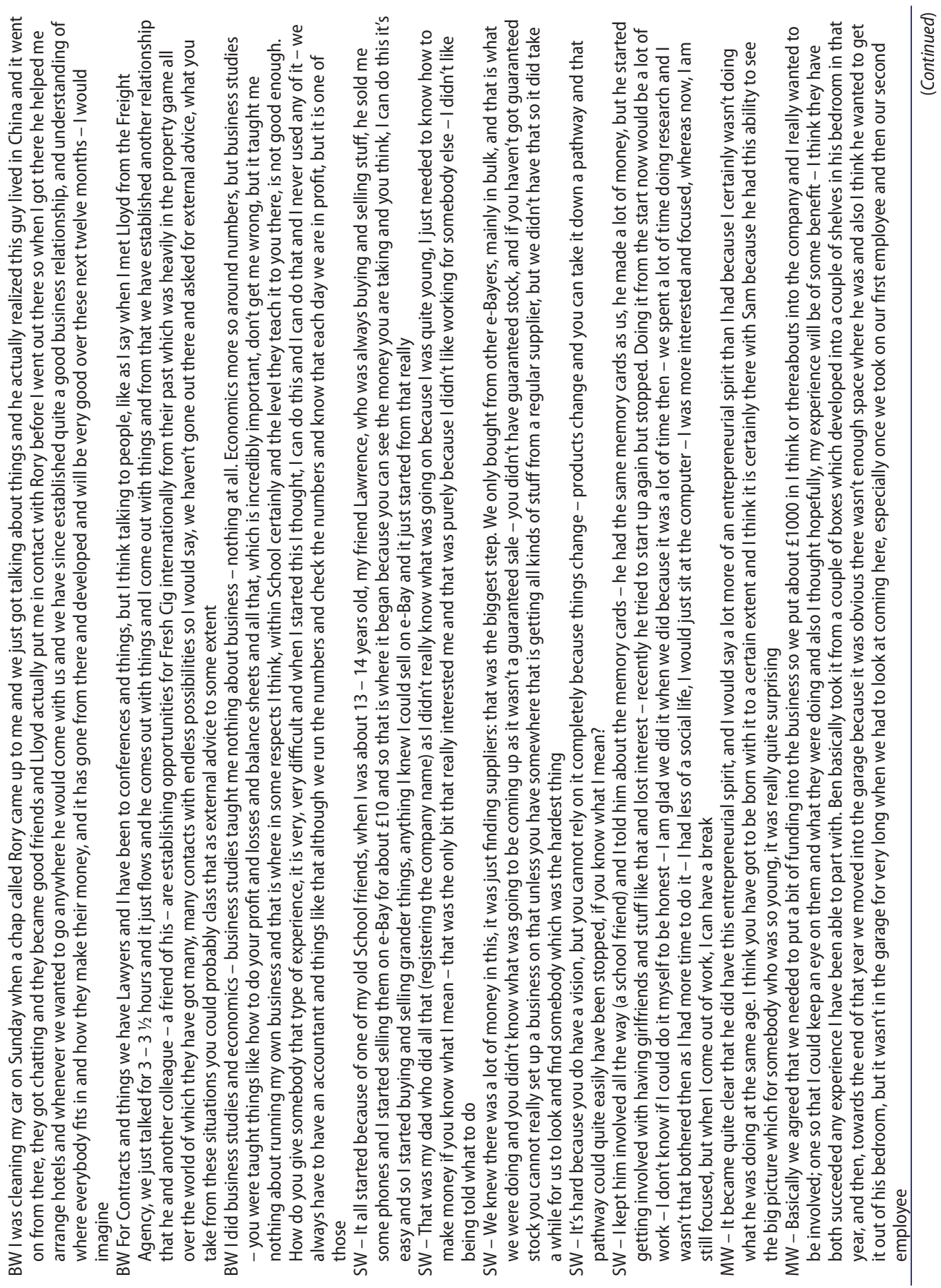




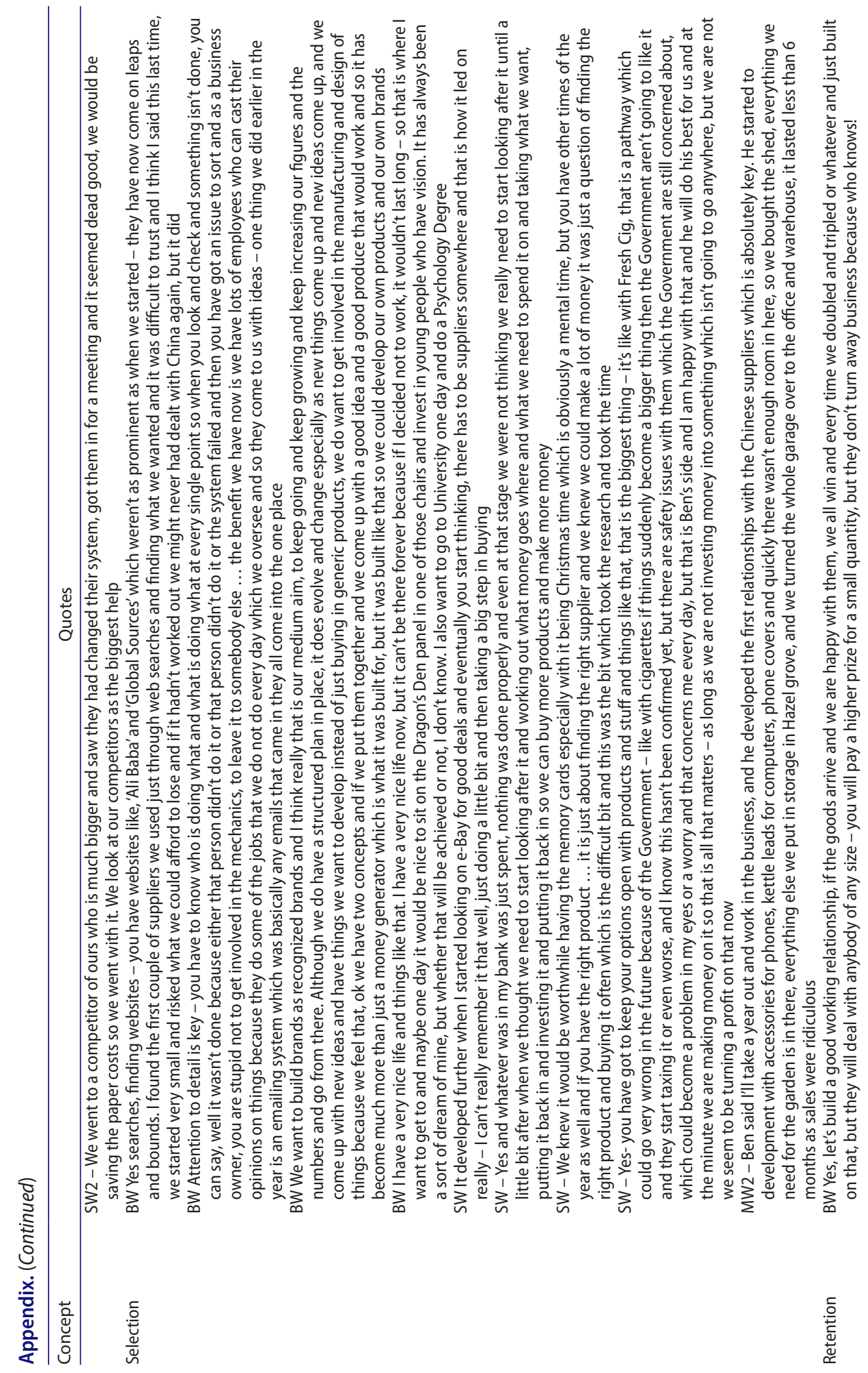




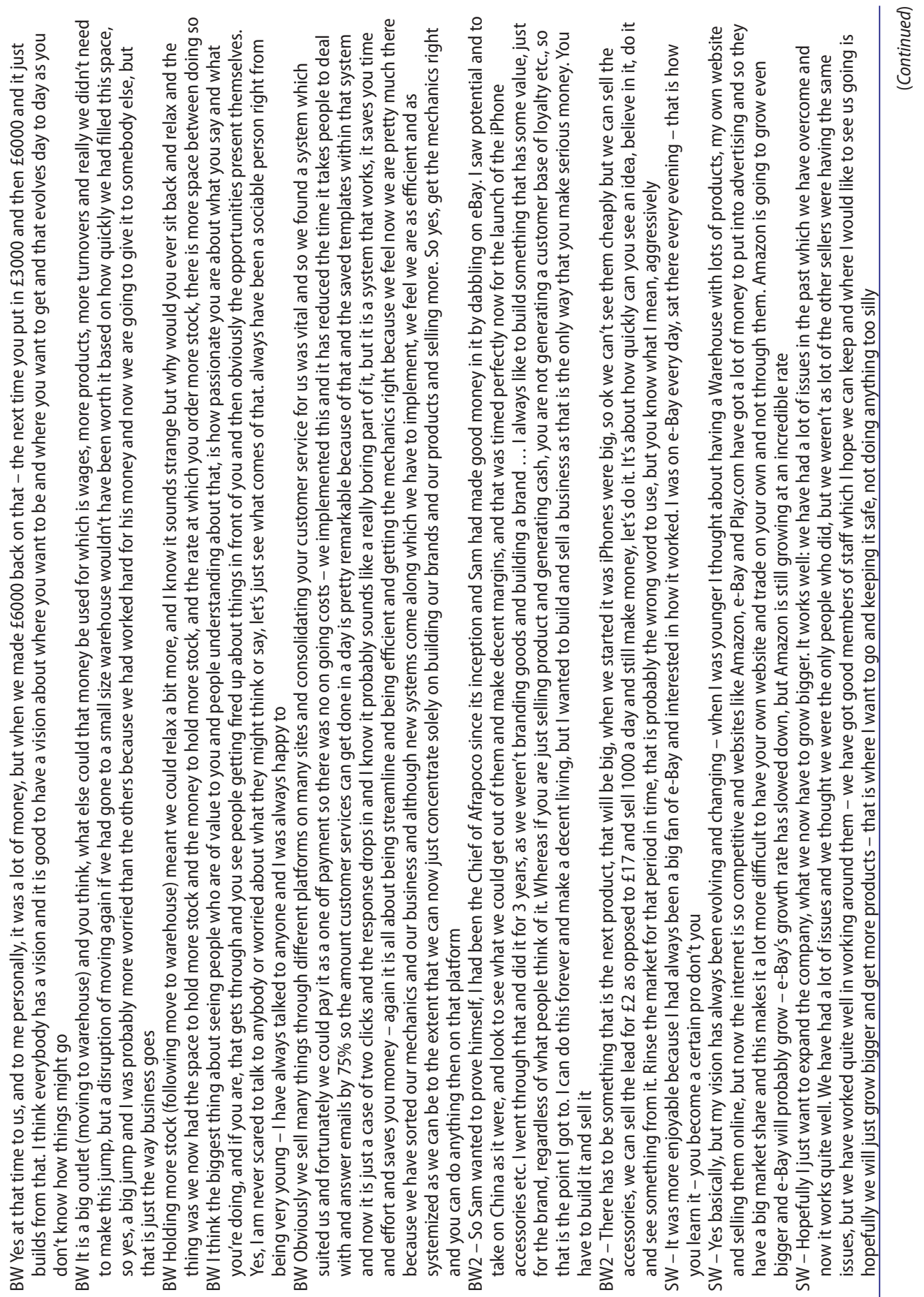




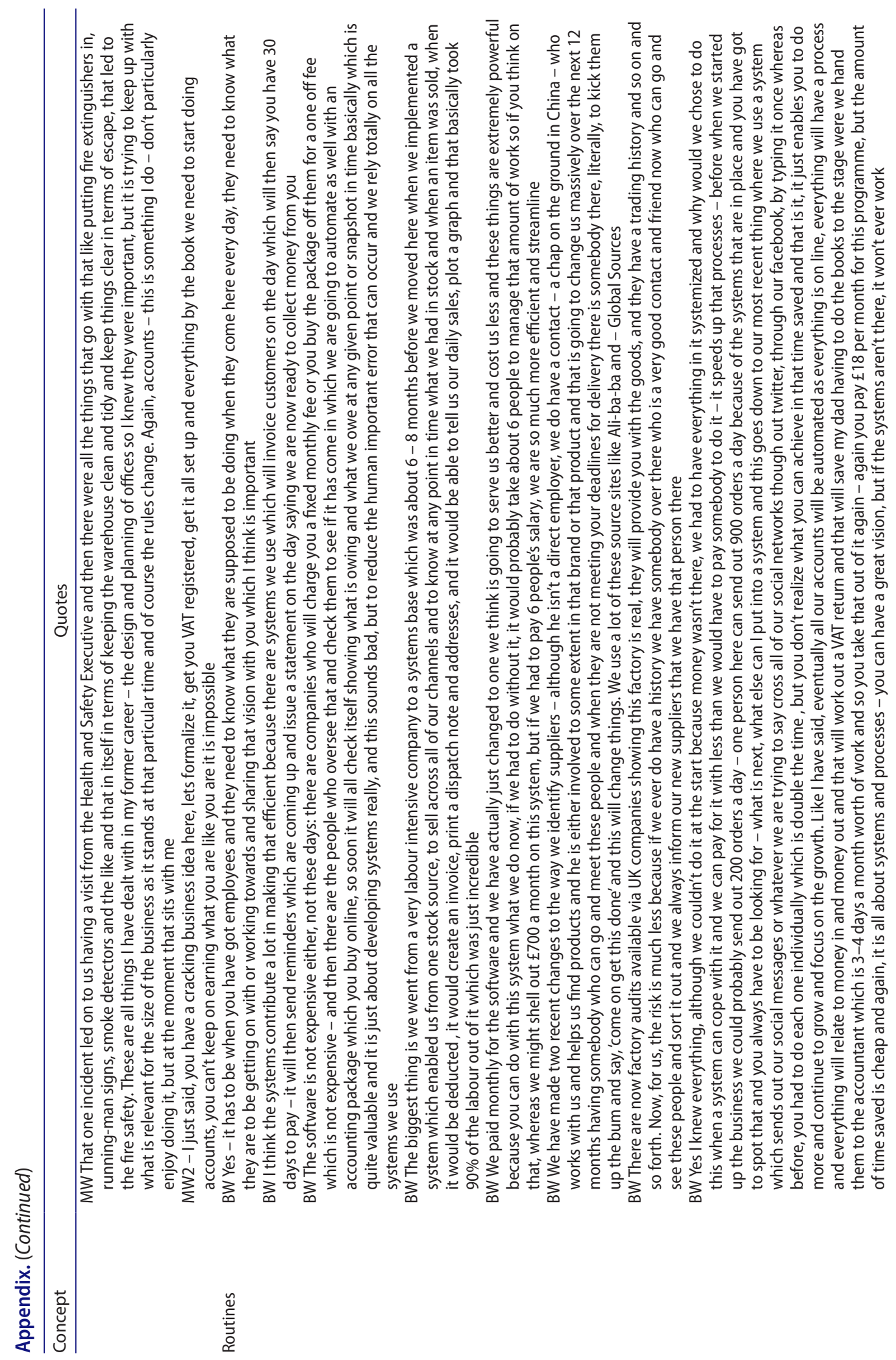




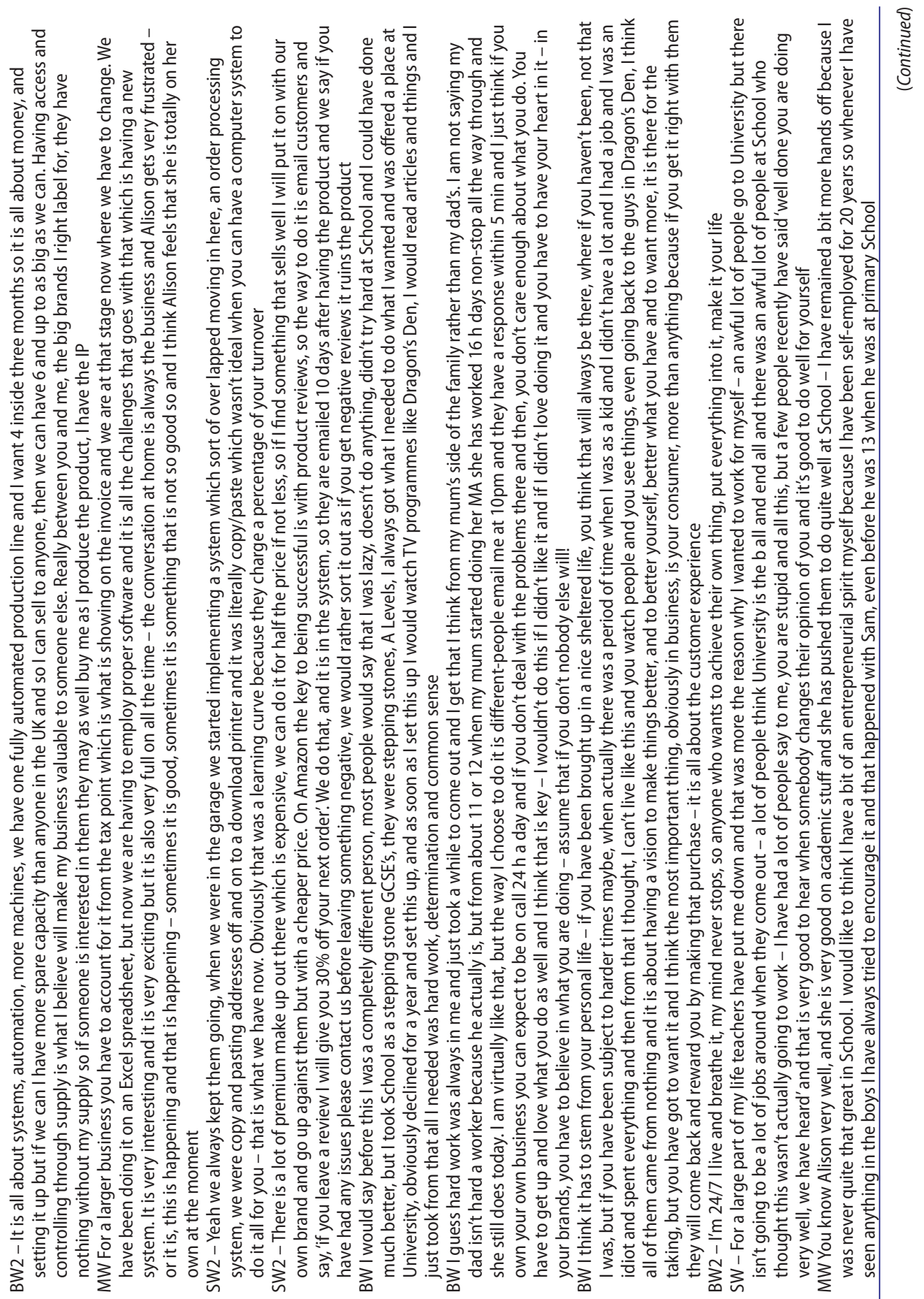




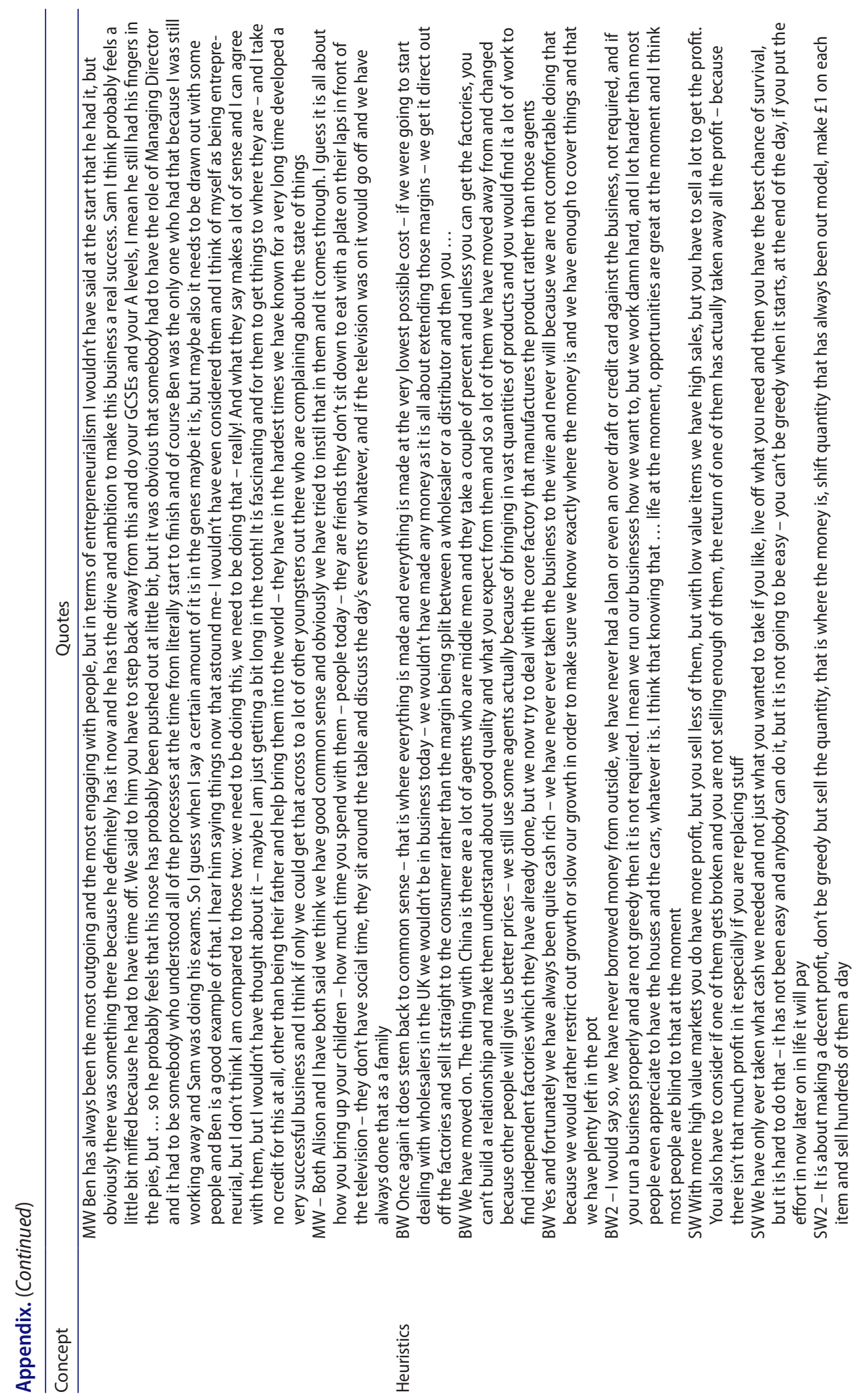



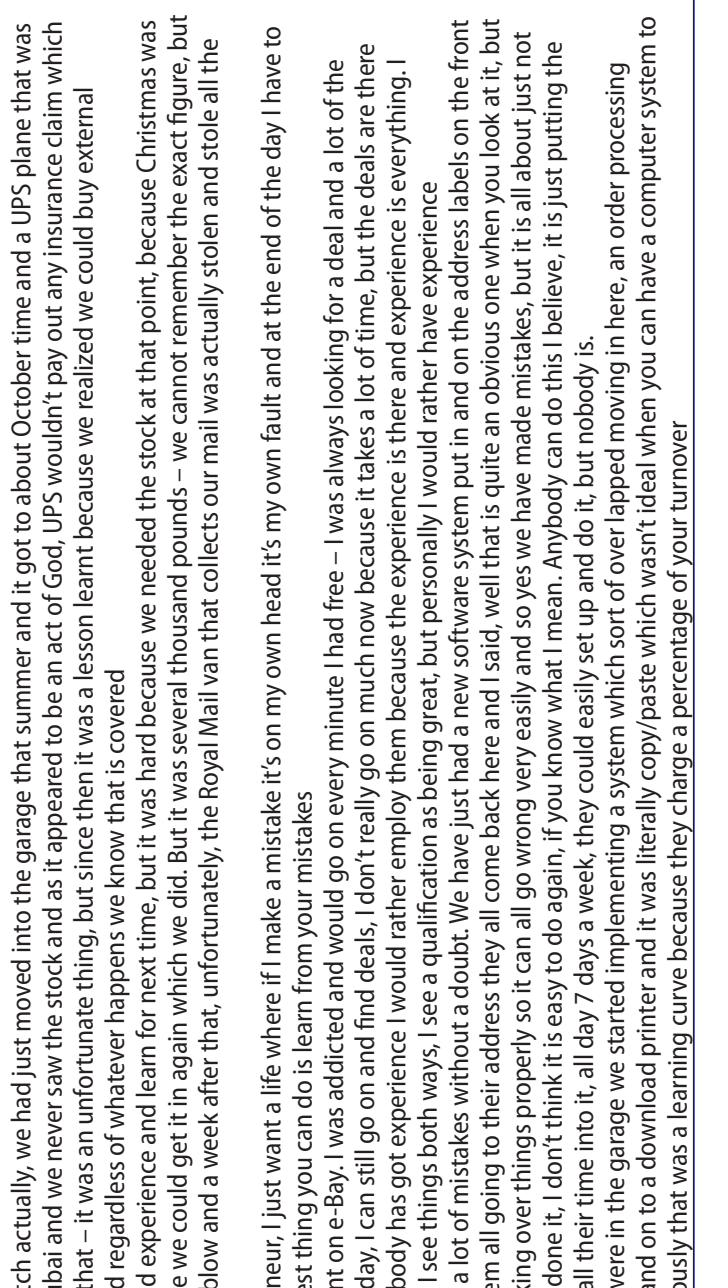

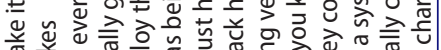

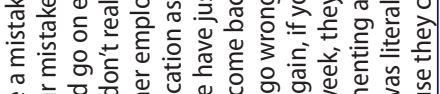

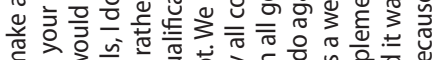

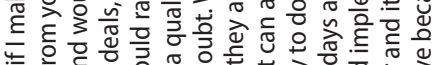

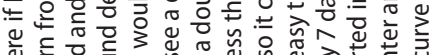

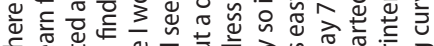

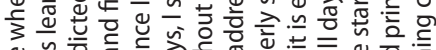

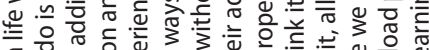

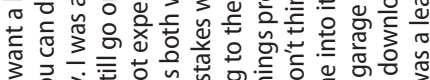

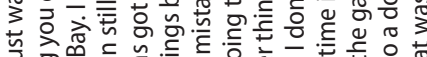

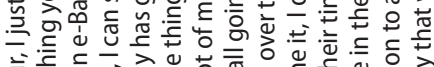

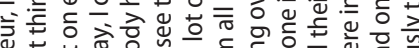

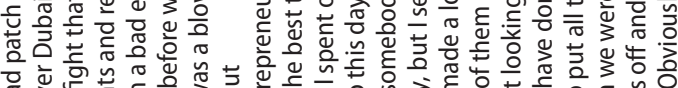

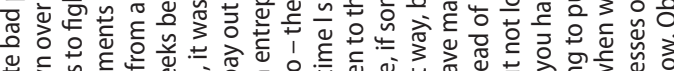

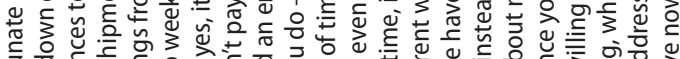

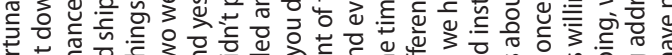

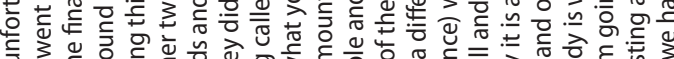

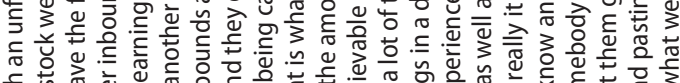

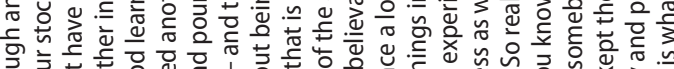

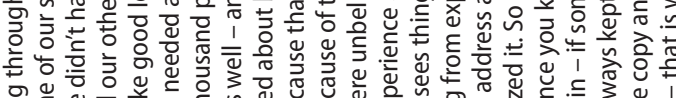

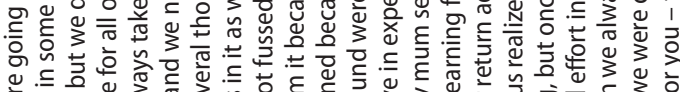

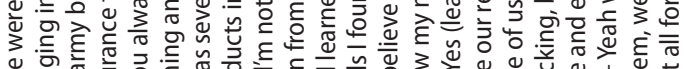

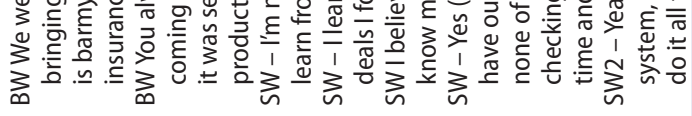

